\title{
GRAVITY-BASED TOOLS FOR ASSESSING THE IMPACT OF TARIFF CHANGES
}

Arevik Gnutzmann-Mkrtchyan and Jules Hugot

NO. 649

February 2022
ADB ECONOMICS WORKING PAPER SERIES 


\section{ADB Economics Working Paper Series}

\section{Gravity-Based Tools for Assessing the Impact of Tariff Changes}

Arevik Gnutzmann-Mkrtchyan and Jules Hugot

No. 649 | February 2022
Arevik Gnutzmann-Mkrtchyan (arevik.gnutzmann@ mkrtchyan.info) is an assistant professor at the Leibniz Universität Hannover. Jules Hugot (jhugot@adb.org) is an economist at the Economic Research and Regional Cooperation Department, Asian Development Bank.

The authors thank Lilia Aleksanyan (ADB), Pramila Crivelli (ADB), Grigor Gyurjyan (ADB), and Yoto V. Yotov (Drexel University) for their insightful comments. The authors are also grateful to Narek Ohanyan for providing support in the preparation of data and charts. 
(C) 2022 Asian Development Bank 6 ADB Avenue, Mandaluyong City, 1550 Metro Manila, Philippines

Tel +632 8632 4444; Fax +63286362444

www.adb.org

Some rights reserved. Published in 2022.

ISSN 2313-6537 (print), 2313-6545 (electronic)

Publication Stock No. WPS220053-2

DOI: http://dx.doi.org/10.22617/WPS220053-2

The views expressed in this publication are those of the authors and do not necessarily reflect the views and policies of the Asian Development Bank (ADB) or its Board of Governors or the governments they represent.

ADB does not guarantee the accuracy of the data included in this publication and accepts no responsibility for any consequence of their use. The mention of specific companies or products of manufacturers does not imply that they are endorsed or recommended by ADB in preference to others of a similar nature that are not mentioned.

By making any designation of or reference to a particular territory or geographic area, or by using the term "country" in this document, $A D B$ does not intend to make any judgments as to the legal or other status of any territory or area.

This work is available under the Creative Commons Attribution 3.0 IGO license (CC BY 3.0 IGO)

https://creativecommons.org/licenses/by/3.0/igo/. By using the content of this publication, you agree to be bound by the terms of this license. For attribution, translations, adaptations, and permissions, please read the provisions and terms of use at https://www.adb.org/terms-use\#openaccess.

This CC license does not apply to non-ADB copyright materials in this publication. If the material is attributed to another source, please contact the copyright owner or publisher of that source for permission to reproduce it. $\mathrm{ADB}$ cannot be held liable for any claims that arise as a result of your use of the material.

Please contact pubsmarketing@adb.org if you have questions or comments with respect to content, or if you wish to obtain copyright permission for your intended use that does not fall within these terms, or for permission to use the ADB logo.

Corrigenda to ADB publications may be found at http://www.adb.org/publications/corrigenda.

Notes:

In this publication, "\$” refers to United States dollars.

ADB recognizes "Russia” as the Russian Federation.

The ADB Economics Working Paper Series presents data, information, and/or findings from ongoing research and studies to encourage exchange of ideas and to elicit comment and feedback about development issues in Asia and the Pacific. Since papers in this series are intended for quick and easy dissemination, the content may or may not be fully edited and may later be modified for final publication. 


\section{CONTENTS}

TABLES AND FIGURES iv

ABSTRACT

$\begin{array}{lll}\text { I. INTRODUCTION } & 1\end{array}$

II. THEORETICAL AND EMPIRICAL FRAMEWORKS

A. Structural Gravity 5

B. Partial Equilibrium Tool 6

C. General Equilibrium Tool 10

D. Data 10

III. PRODUCT-LEVEL ESTIMATIONS OF THE TRADE ELASTICITY 12

A. Distribution of Estimated Elasticities 12

B. Customs Union Effect 14

C. Coverage for Armenia 16

\begin{tabular}{ll} 
IV. & CHANGES IN ARMENIA'S TARIFFS \\
\hline
\end{tabular}

A. Eurasian Economic Union $\quad 17$

B. Other Trade Agreements Affecting Armenia 20

C. Trade Agreements between the Eurasian Economic Union and Other Economies 20

V. IMPACT OF TARIFF CHANGES ON ARMENIA 21

A. Convergence to the Eurasian Economic Union Common External Tariff 21

B. Free Trade Agreement between the Eurasian Economic Union and Iran 24

C. Free Trade Agreement between the Eurasian Economic Union and 26 the People's Republic of China

D. Loss of European Union Generalised Scheme of Preference Eligibility 28

$\begin{array}{ll}\text { VI. CONCLUSION } & 31\end{array}$

$\begin{array}{lc}\text { REFERENCES } & 32\end{array}$ 


\section{TABLES AND FIGURES}

\section{TABLES}

1 Impact of the Common External Tariff of the Eurasian Economic Union on Armenia's Trade and Welfare

2 Impact of Potential Free Trade Agreements on Armenia's Trade and Welfare: General Equilibrium Tool

3 Impact of the Loss of European Union Generalised Scheme of Preferences Eligibility on Armenia's Welfare and Manufacturing Exports

4 Free Trade Agreements Involving Armenia 20

$5 \quad$ Armenia's Exports to the European Union: 2018

\section{FIGURES}

1 Variance Decomposition of Tariffs Across Sectors 8

2 Distribution of Estimated Trade Elasticities 13

3 Distribution of Estimated Trade Elasticities Across Levels of Confidence 13

4 Distribution of Trade Elasticities Significant at the 10\% Level, Across Sectors 14

5 Distribution of Negative and Significant Trade Elasticities: Gravity Controls 15 and Pair Fixed Effects Specifications

6 Distribution of Customs Union Coefficients 15

7 Coverage of Armenia's Trade by Negative-Significant Trade Elasticities 16 Gravity-Controls and Pair Fixed Effects Specifications

8 Armenia's Trade During 1995-2018 Covered by Negative-Significant 16 Trade Elasticities

9 Transition Schedule for Armenia's Exceptions from the Eurasian Economic 18 Union Common External Tariff

10 Armenia's Average Tariff and Share of Duty-Free Tariff Lines 18

11 Distribution of Armenia's Tariffs 19

12 Armenia's Trade-Weighted Average Tariff Across Sectors 19

13 Impact of the Convergence to the Eurasian Economic Union Common External 22 Tariff on Armenia

14 Impact of the Convergence to the Eurasian Economic Union Common External 23 Tariff on Armenia's Imports, by Partner

15 Impact of the Convergence to the Eurasian Economic Union Common External 24 Tariff on Armenia's Imports, by Sector

16 Sector Composition of Armenia-Iran Trade 
17 Welfare and Trade Impact of Eurasian Economic Union-Iran

Free Trade Agreement, by Partner

18 Trade Impact of Eurasian Economic Union-Iran Free Trade Agreement, by Sector

19 Sector Composition of Armenia-People's Republic of China Trade

20 Welfare and Trade Impact of Eurasian Economic Union-People's Republic of China Free Trade Agreement, by Partner

21 Trade Impact of Eurasian Economic Union-People's Republic of China

Free Trade Agreement, by Sector

22 Sector Composition of Armenia-European Union Trade 28

23 Welfare and Trade Impact of the Loss of European Union Generalised Scheme 29 of Preferences Eligibility, by Partner

24 Impact of the Loss of European Union Generalised Scheme of Preferences 


\begin{abstract}
This paper presents two empirical tools to quantify the impacts of tariff changes on bilateral trade and welfare. Both tools are rooted in the structural gravity literature. The first tool estimates the impact of tariff changes on bilateral trade for 5,020 products in a partial equilibrium framework. The second tool quantifies the impact on bilateral aggregate trade in a general equilibrium setup, allowing estimates of trade reallocation and welfare changes. These tools are used to estimate the impact of tariff changes affecting Armenia, including (i) the alignment with the external tariff of the Eurasian Economic Union, (ii) free trade agreements between the Eurasian Economic Union, and other economies - Iran and the People's Republic of China, and (iii) the loss of beneficiary status for the Generalised Scheme of Preferences of the European Union.
\end{abstract}

Keywords: gravity, Eurasian Economic Union, free trade agreements, generalised scheme of preferences, Armenia

JEL codes: F13, F14, F15, F17 


\section{INTRODUCTION}

This paper introduces two empirical tools to quantify the impact of tariff changes on trade and welfare. The tools can assess the impact of any trade policy change that can be mapped to tariff changes. The approach combines the literature on the structural gravity model (Arkolakis, Costinot, and Rodríguez-Clare 2012, hereafter ACR 2012; Head and Mayer 2014; Yotov et al. 2016) with product-level bilateral trade data (CEPII 2021).' These tools complement each other. They can inform policy makers, business communities, or the public on the impact of policies such as bilateral trade agreements and preferential tariff schemes.

Assessments of the impact of trade policy changes aimed at policy makers often rely on computable general equilibrium (CGE) models, notably the Global Trade Analysis Project (GTAP). The structural gravity framework, on the other hand, has mostly remained within academic circles. This paper aims to bridge this gap by proposing practical tools rooted in the gravity literature to quantify the impact of tariff changes.

CGE models are generally complex as they explicitly model labor and capital markets, natural resources, investment and savings patterns, etc. As such, they may uncover unexpected consequences of trade policy changes. CGE models also rely on numerous elasticities to capture responses by certain variables to changes in others. These elasticities are taken from studies that often estimate them using data for advanced economies. This complexity limits the ability of these models to attribute effects to specific mechanisms. CGE models also have high data requirements, which constrain the questions they can address in terms of time and geographical coverage, or product detail. ${ }^{2}$ For smaller economies, the data underlying GTAP are also often outdated. For example, input-output data for Armenia in the latest version of GTAP is from 2002.

The structural gravity model is also a general equilibrium model-it accounts for indirect linkages between economies while imposing market clearing in all markets-but it is much simpler. The elasticities required to quantify the impacts of tariff changes can be estimated using data relevant to the focus of the analysis. The gravity model allows eliciting of the mechanisms that lead from tariff changes to their effects. It is also less demanding than CGE models in terms of data. It can thus answer questions on distant periods and smaller economies, or at high levels of product detail. The gravity model also closely fits historical data, while CGE models are difficult to test against data.

The first tool relies on a partial equilibrium reading of the gravity model. This partial equilibrium tool generates trade impacts across 5,020 products facing tariff changes. This tool requires productlevel elasticities of trade-to-trade costs. These elasticities are estimated using two specifications anchored in the structural gravity literature. The first one includes the usual gravity controls and is similar to Fontagné, Guimbard, and Orefice (2019), hereafter FGO (2019). The second specification follows the structural gravity model even more closely, by including pair fixed effects. The elasticities estimated with pair fixed effects are on average closer to zero (less negative) than those from the specification with gravity controls. This suggests the latter are biased downwards as unobserved trade costs-those not controlled for in the specification with gravity controls-are positively correlated

\footnotetext{
The bilateral trade data comes from the BACI database (CEPII 2021), which as of February 2021 only covered up to 2018.

2 As an example, the 2019 iteration of GTAP covers 121 economies plus 20 regions, for 4 years (2004, 2007, 2011, and 2014), and distinguishes 65 sectors (including services).
} 
with tariffs. The estimations are performed on data for 1995-2018, while FGO (2019) use data for every third year during 2001-2016. ${ }^{3}$

The elasticities are then combined with scenarios of tariff changes to predict the impact on trade at the product level. The product-level detail makes this tool relevant for stakeholders such as trade negotiators (to assess alternative deals), local governments, and business communities (to assess impacts on specific industries). This distinction provides an important advantage over models relying on sector data as trade agreements are negotiated on highly disaggregated products. In addition, economic outcomes may depend on concessions or exceptions for very specific productsparticularly for small economies as they tend to be more specialized.

The general equilibrium tool also estimates the impact of tariff changes on bilateral trade but both tariffs and trade are aggregated across products. Contrary to the first tool, it captures the indirect impact of tariff changes on trade, also known as trade reallocation. An increase in tariffs between two economies reduces trade between them-this is the direct effect. But these tariff increases also make trade with other economies cheaper, in relative terms. This pushes some trade to reallocate to partners not affected by tariff changes-this is the indirect effect. Other than bilateral trade, the general equilibrium approach also requires data on domestic consumption. However, this data is not available at the Harmonized System (HS) classification 6-digit product level, and is limited to manufacturing. The general equilibrium tool thus relies on aggregate manufacturing data. In short, this second tool quantifies the indirect impact of tariff changes, but at the cost of losing the product granularity of the first tool and reducing the coverage to manufacturing. As the general equilibrium tool excludes sectors such as commodities, the corresponding results should be taken as lower bound estimates of the impact of tariff changes.

The general equilibrium tool also estimates the impact of tariff changes on welfare for all countries, including those not directly affected by the tariff changes. The welfare estimations also proceed from the structural gravity model, following ACR (2012). They are implemented using a routine proposed by Baier, Yotov, and Zylkin (2019) and inspired by Head and Mayer (2014).

Both tools are used in this paper to estimate the impacts of three recent or potential series of tariff policy changes affecting Armenia: (i) the convergence to the common external tariff (CET) of the Eurasian Economic Union (EEU); (ii) free trade agreements (FTA) between the EEU and Iran, and the EEU and the People's Republic of China (PRC); and (iii) the end of eligibility to the European Union's (EU) Generalised Scheme of Preferences (GSP). ${ }^{4}$

Armenia has been a member of the EEU since 2015, together with Belarus, Kazakhstan, the Kyrgyz Republic, and the Russian Federation. Armenia had pursued a liberal trade policy since 1991, with an average most favored nation (MFN) tariff at 2.9\% in 2014. Accession to the EEU required that its tariffs converge to the EEU CET, which was 6.0\% in 2015. To ease the convergence, Armenia received exemptions for $6.3 \%$ of the products listed in the CET, accounting for 38\% of Armenia's imports from outside the EEU (WTO 2018), with a transition period until 31 December 2021.

3 Trade data before 1995 for most former Soviet Union countries are missing. The last year with available tariff and trade data is 2018. Tariff data are from the Trade Analysis Information System (TRAINS) (UNCTAD 2021), while FGO (2019) use data from MacMap (International Trade Center 2021).

4 ADB (2021) estimates that the EEU-Serbia FTA (signed on 25 October 2019) will have a negligible impact, as would a potential EEU-India FTA. 
The EEU only affects the tariffs imposed by Armenia on its imports, as exports to all EEU members were already duty-free. The general equilibrium results suggest that the alignment to the EEU CET will reduce welfare in Armenia by $1.6 \%$, and imports from outside the EEU by $4.1 \%$, mostly from the EU and the PRC (Table 1). The CET is also expected to increase imports from the EEU and the other partners with which Armenia trades duty free by $2.5 \%$, including the Russian Federation, Ukraine, and Viet Nam.

The partial equilibrium tool suggests that import reductions from outside the EEU will concentrate on vehicles, pharmaceuticals, and plastics. Convergence to the CET also implies tariff reductions for about $20 \%$ of tariff lines. These are estimated to increase imports of electronics, fruit, coffee, and tea.

\section{Table 1: Impact of the Common External Tariff of the Eurasian Economic Union on Armenia's Trade and Welfare}

\begin{tabular}{lccccc}
\hline & Welfare Impact & Import Destruction & Import Creation & \multicolumn{2}{c}{ Net Impact on Imports } \\
\cline { 2 - 6 } Tool & $\%$ & $\$$ million & \$ million & \$ million & \% of total \\
\hline General equilibrium & $(1.6 \%)$ & $(145)$ & 90 & $(54)$ & $(1.5 \%)$ \\
Partial equilibrium & - & $(709)$ & 117 & $(592)$ & $(12.3 \%)$ \\
\hline
\end{tabular}

()$=$ negative,$-=$ not applicable.

Source: Authors' calculations.

EEU membership also improves market access for Armenia through the FTAs negotiated by the EEU. The paper assesses the impact of potential EEU-PRC and EEU-Iran FTAs. ${ }^{5}$ The general equilibrium analysis suggests that together, the two FTAs would increase Armenia's welfare by $1.0 \%$.

Results suggest that an EEU-Iran FTA would increase Armenia's welfare by $0.3 \%$, total manufacturing exports by $0.7 \%$, and imports by $0.4 \%$; with exports to Iran almost doubling (Table 2 ). The partial equilibrium tool suggests that Armenia would export more vehicles, chemicals, and confectionery to Iran; and import more plastics, mineral fuels, and iron from Iran. An EEU-PRC FTA would boost Armenia's welfare by $0.7 \%$, manufacturing exports by $0.6 \%$, and imports by $0.3 \%$. Bilateral exports would increase for vehicles and clothing; and imports would increase for electronics, vehicles, engines, and furniture. Both FTAs would also involve some trade reallocation away from the Russian Federation.

Armenia was granted GSP+ benefits in 2009 , obtaining duty-free access to the EU for $66 \%$ of tariff lines. However, EU legislation provides that a country classified by the World Bank as upper middle-income for three consecutive years should stop benefitting from GSP arrangements (EU 2012). As it has been classified as an upper middle-income country since fiscal year 2019 (ended 30 June 2019), eligibility ceased for Armenia on 1 January 2022 (EU 2021).

5 The scenario for Iran extends beyond the interim agreement in force since October 2019. The full-coverage assumption is critical as key export opportunities for Armenia concentrate on a few products. e.g., liquor, tobacco. 
Table 2: Impact of Potential Free Trade Agreements on Armenia's Trade and Welfare: General Equilibrium Tool

\begin{tabular}{|c|c|c|c|c|c|c|c|}
\hline \multirow[b]{2}{*}{ Scenario } & \multicolumn{2}{|c|}{ Welfare Impact } & \multicolumn{3}{|c|}{ Manufacturing Exports } & \multicolumn{2}{|c|}{ Manufacturing Imports } \\
\hline & $\%$ & $\begin{array}{c}\$ \\
\text { million }\end{array}$ & $\begin{array}{c}\% \\
\text { of total }\end{array}$ & $\begin{array}{c}\% \\
\text { of bilateral }\end{array}$ & $\begin{array}{c}\$ \\
\text { million }\end{array}$ & $\begin{array}{c}\% \\
\text { of total }\end{array}$ & $\begin{array}{c}\% \\
\text { of bilateral }\end{array}$ \\
\hline \multicolumn{8}{|l|}{ EEU-Iran FTA } \\
\hline Total for Armenia & $0.29 \%$ & 14.0 & $0.7 \%$ & - & 13.9 & $0.4 \%$ & - \\
\hline Trade with Iran & - & 22.0 & $1.1 \%$ & $95.7 \%$ & 41.2 & $1.2 \%$ & $23.7 \%$ \\
\hline $\begin{array}{l}\text { Trade with Russian } \\
\text { Federation }\end{array}$ & - & $(2.3)$ & $(0.4 \%)$ & $(0.4 \%)$ & $(9.5)$ & $(0.3 \%)$ & $(1.0 \%)$ \\
\hline \multicolumn{8}{|l|}{ EEU-PRC FTA } \\
\hline Total for Armenia & $0.66 \%$ & 10.7 & $0.6 \%$ & - & 10.8 & $0.3 \%$ & - \\
\hline Trade with the PRC & - & 12.0 & $0.6 \%$ & $41.4 \%$ & 96.9 & $2.7 \%$ & $20.3 \%$ \\
\hline $\begin{array}{l}\text { Trade with Russian } \\
\text { Federation }\end{array}$ & - & $(8.1)$ & $(0.4 \%)$ & $(1.5 \%)$ & $(22.2)$ & $(0.6 \%)$ & $(2.4 \%)$ \\
\hline
\end{tabular}

()$=$ negative,$-=$ not applicable, EEU = Eurasian Economic Union, FTA = free trade agreement, PRC = People's Republic of China. Source: Authors' calculations.

The general equilibrium results suggest that the loss of GSP eligibility will reduce Armenia's welfare by $0.1 \%$, and manufacturing exports to the EU by $12 \%$ (Table 3 ). Conversely, exports to the Russian Federation are projected to increase by $2 \%$. The partial equilibrium analysis suggests that the impact will concentrate on exports of iron and steel (largely ferromolybdenum), aluminum foil, and textiles.

\section{Table 3: Impact of the Loss of European Union Generalised Scheme of Preferences Eligibility on Armenia's Welfare and Manufacturing Exports}

\begin{tabular}{|c|c|c|c|c|}
\hline \multirow[b]{2}{*}{ Scenario } & \multicolumn{2}{|c|}{ Impact on Welfare } & \multicolumn{2}{|c|}{ Impact on Manufacturing Exports } \\
\hline & $\%$ & \$ million & $\begin{array}{l}\% \text { of total } \\
\text { exports }\end{array}$ & $\begin{array}{l}\% \text { of bilateral } \\
\text { exports }\end{array}$ \\
\hline General equilibrium net impact & $(0.14 \%)$ & $(17.0)$ & $(0.9 \%)$ & - \\
\hline of which exports to the EU & - & $(34.9)$ & $(1.8 \%)$ & $(11.6 \%)$ \\
\hline of which exports to the Russian Federation & & 8.8 & $0.4 \%$ & $1.6 \%$ \\
\hline Partial equilibrium impact on exports to the EU & & $(157)$ & $(3.3 \%)$ & $(18.7 \%)$ \\
\hline
\end{tabular}

( ) = negative,$-=$ not applicable, EU = European Union.

Source: Authors' calculations. 


\section{THEORETICAL AND EMPIRICAL FRAMEWORKS}

This section introduces the theoretical and empirical frameworks, both rooted in the structural gravity literature.

\section{A. Structural Gravity}

The original gravity model is an empirical relationship describing bilateral trade proportional to the gross domestic products (GDP) of the partners and inversely proportional to the distance between them. Proposed by Tinbergen (1962), this relationship is known as the gravity equation due to its similarity to Isaac Newton's equation.

Although empirically powerful, the gravity equation lacked theoretical foundations until the early 2000s. Eaton and Kortum (2002) derived gravity equations from a Ricardian model and Anderson and van Wincoop (2003) derived gravity equations from a national product differentiation model. Chaney (2008) derived a similar gravity equation from a heterogeneous trade model expanding on Melitz (2003). The structural gravity equation is:

$$
X_{i j}=\frac{Y_{i}}{\Pi_{i}} \frac{E_{j}}{P_{j}} \tau_{i j}^{\varepsilon}
$$

where $X_{i j}$ denotes exports from location $i$ to location $j . Y_{i}$ is $i$ 's production. $E_{j}$ is $j$ 's total expenditure. $\tau_{i j}$ represents bilateral trade costs between $i$ and $j$.

The key feature in structural gravity is the "multilateral resistance terms." $\Pi_{i}$ is the outward resistance term, measuring exporter i's market access:

$$
\Pi_{i}=\sum_{\ell} \frac{\tau_{i \ell} E_{\ell}}{P_{\ell}}
$$

$P_{j}$ is the inward resistance term, measuring importer $j$ 's accessibility for imports:

$$
P_{j}=\sum_{\ell} \frac{\tau_{\ell j} Y_{\ell}}{\Pi_{\ell}}
$$

where $\ell$ identifies partners other than $i$ and $j$.

These two terms $\left(\Pi_{i}\right.$ and $P_{j}$ ) capture the overall trade restrictiveness of partners. They highlight that bilateral trade is also linked to the alternative options available to each partner. For example, Australia and New Zealand trade four times more than Greece and Spain, despite Australia and Spain having similar GDPs, and Greece and New Zealand's GDPs being similar. The geographic distance between the two pairs is also similar. ${ }^{6}$ The multilateral resistance terms imply that the structural gravity model cannot be solved analytically. The general equilibrium tool thus relies on a numerical resolution of the model.

6 In 2018, total trade between Australia and New Zealand was $\$ 12.3$ billion ( $\$ 3.8$ billion between Greece and Spain). Australia's GDP was $\$ 1,433$ billion ( $\$ 1,420$ billion for Spain); and both Greece and New Zealand's GDPs were $\$ 212$ billion. The distance between Sydney and Wellington is 2,232 km (2,383 km between Athens and Madrid). 
In equation $1, \varepsilon$ is the elasticity of bilateral trade to trade costs, referred to in the literature as the "trade elasticity". The interpretation of this elasticity varies across the micro-foundations of the structural gravity equation. In the national product differentiation model (Anderson and van Wincoop 2003), $\varepsilon=1-\sigma$, where $\sigma>1$ is the elasticity of substitution across varieties. Intuitively, when a product can easily be replaced by another (large $\sigma$ ), a small increase in trade frictions will cause a large decline in trade. In the Ricardian model (Eaton and Kortum 2002) and the heterogeneous firms model (Chaney 2008), $\varepsilon=-\theta$, where $\theta$ reflects heterogeneity in the productivity distribution. In these models, trade gains arise because sector- and firm-level productivities vary across countries. The larger $\theta$ (more homogeneous productivities), the smaller the trade gains, and the larger the sensitivity of trade to trade costs.

\section{B. Partial Equilibrium Tool}

The partial equilibrium tool relies on two steps: (i) estimating product-level trade elasticities, and (ii) combining them with each tariff change scenario.

\section{Step 1: Estimation of Product-level Trade Elasticities}

Trade elasticities are not only necessary as an input to compute direct trade impacts in the partial equilibrium tool, they are also a crucial input to compute the welfare impact of tariff changes. ACR (2012) show that in a wide range of models leading to structural gravity equations, the welfare impact of changes in trade is a function of (i) changes in the ratio of domestic-to-total expenditure, and (ii) the trade elasticity.

Feenstra (1994), Broda and Weinstein (2006), and Ossa (2015) estimate product-level elasticities of substitutions across varieties $(\sigma)$ using an import demand function. These elasticities can then be mapped to trade elasticities $(\varepsilon=1-\sigma)$. They estimate these elasticities as the response of imports to changes in the relative prices of varieties (product-country combinations). Both estimate these elasticities to assess welfare gains from increased diversity in imported varieties, as per Krugman's (1979) monopolistic competition trade model. Feenstra (1994) estimates elasticities for six products using United States (US) import data. Broda and Weinstein (2006) estimate elasticities for US imports, with a breakdown across 11,040 products during 1972-1988, and 13,972 products during 1990-2001. Ossa (2015) extends the ACR (2012) welfare analysis to allow for sector-level heterogeneity. He estimates trade elasticities using data on 49 countries and for 251 sectors in 2007. He finds that the welfare impacts of trade changes increase by a factor of three when computed using the ACR (2012) formula at the sector level instead of using aggregate data and a single trade elasticity.

Estimations in this paper rely on the structural gravity framework and use tariffs to identify trade elasticities. In that, they are closer to Caliendo and Parro (2015) and like in FGO (2019). Caliendo and Parro (2015) use the multiplicative structure of the gravity equation to cancel out unobserved symmetric trade costs (i.e., those that pertain to a country pair regardless of their direction). Their identification relies on asymmetries in tariffs between partners. They estimate elasticities for 20 sectors in 1993. FGO (2019) estimate product-level trade elasticities through a fixed-effects specification. They use bilateral tariffs to identify trade elasticities, controlling for other observable bilateral trade costs. Like Ossa (2015), they find that product-level elasticities magnify the welfare impact of trade, particularly for lower income economies. ${ }^{7}$ This paper expands on their work by

7 This magnification is larger for countries where products with low trade elasticities - such as food and raw materials —are either a large share of consumption or are largely imported. 
estimating elasticities using country-pair fixed effects. These fixed effects control for observable bilateral features - such as distance and common language-but also for other bilateral time-invariant features. However, tariffs vary across country pairs more than they do across time, leading to a smaller number of significant elasticities.

Extensive literature has converged to best-practice recommendations for estimating structural gravity models (Head and Mayer 2014, Yotov et al. 2016). This paper follows this literature and performs estimations using data for 1995-2018. As the gravity model is separable across products, estimations are performed for each 6-digit product. ${ }^{8}$ To avoid overloading the notation, product subscripts are not reported in the equations below.

First, tariff elasticities are estimated with a panel data specification including the appropriate structure of fixed effects. Time subscripts $(t)$ are added to account for the panel structure. As multilateral resistance terms are not observable, all exporter-year and importer-year-specific variables are replaced by origin-year and destination-year fixed effects. These fixed effects capture production, expenditure, and multilateral resistance.

Second, estimations are performed using the Poisson pseudo maximum likelihood (PPML) estimator. Santos Silva and Tenreyro (2006) show that log-linear estimations of the gravity equation can be inconsistent and recommend an estimation in multiplicative form using the PPML estimator. The PPML estimator also allows zero trade flows to be included while they disappear through loglinearization. ${ }^{9}$

Product-level tariff elasticities are estimated using two specifications: with gravity controls and with pair fixed effects. In both, standard errors are clustered at the country-pair level.

\section{Specification with gravity controls}

The specification with gravity controls includes observable bilateral features known to affect trade costs. Bilateral trade costs are specified as:

$$
\begin{aligned}
\tau_{i j t}= & \left(1+\operatorname{Tariff}_{i j t}\right) \times \exp \left(\beta_{1} \mathrm{CU}_{i j t}\right) \times \exp \left(\beta_{2} \operatorname{Conti}_{i j}\right) \\
& \times \exp \left(\beta_{3} \operatorname{Coml}_{i j}\right) \times \exp \left(\beta_{4} \operatorname{Colo}_{i j}\right) \times \operatorname{Dist}_{i j}^{\beta_{5}},
\end{aligned}
$$

where Tariff $_{i j t}$ is the bilateral product-level tariff. $\mathrm{CU}_{i j t}, \mathrm{Conti}_{i j}, \mathrm{Coml}_{i j}$, and $\mathrm{Colo}_{i j}$ are dummy variables respectively accounting for customs unions, common borders, common languages, and colonial relationships as of 1945. Dist $i j$ is the population-weighted bilateral distance between the most populated cities in $i$ and $j$.

Plugging equation 4 into equation 1 and replacing non-bilateral variables by fixed effects leads to the following specification:

\footnotetext{
8 To remain consistent with structural gravity, estimating elasticities on a dataset including all products would require importer-exporter-product, importer-product-year, and exporter-product-year fixed effects. This would require computing power not available to the authors.

9 The estimations are made using ppmlhdfe, a Stata command for gravity estimations with high-dimensional fixed effects.
} 


$$
\mathrm{X}_{i j t}=\exp \left[\begin{array}{c}
\varepsilon \times \ln \left(\text { Tariff }_{i j t}\right)+\gamma_{1} \times \mathrm{CU}_{i j t}+\gamma_{2} \times \operatorname{Conti}_{i j}+\gamma_{3} \\
\times \operatorname{Coml}_{i j}+\gamma_{4} \times \operatorname{Colo}_{i j}+\gamma_{5} \times \ln \left(\text { Dist }_{i j}\right)+\pi_{i t}+\chi_{j t}
\end{array}\right] \times \varepsilon_{i j t}
$$

$\pi_{i t}$ and $\chi_{j t}$ denote exporter-year and importer-year fixed effects. The coefficient of interest is $\varepsilon$-the product-level tariff elasticity. Note that for each $\gamma$ and $\beta$ in [1-5], $\gamma=\varepsilon \times \beta$.

\section{Specification with pair fixed effects}

Both bilateral trade and bilateral tariffs vary across country pair and year. This enables estimation of the tariff elasticity while including country-pair fixed effects to control for time-invariant bilateral trade costs (e.g., geography and cultural commonalities). If country-pair fixed effects are included, timeinvariant trade costs can be removed from equation 4, leading to the following specification:

$$
\mathrm{X}_{i j t}=\exp \left[\varepsilon \times \ln \left(\text { Tariff }_{i j t}\right)+\gamma_{1} \times \mathrm{CU}_{i j t}+\pi_{i t}+\chi_{j t}+\mu_{i j}\right] \times \varepsilon_{i j t}
$$

This specification is implied by the structural gravity equation as it controls for any bilateral time-invariant features, not only those included in equation 4.

Tariffs mostly vary across country pairs (between variance), not across time (within variance) (Figure 1). Bilateral fixed effects thus leave little variation to identify tariff elasticities. This generates nonsignificant tariff elasticities for many products. The empirical exercise applied to Armenia thus relies on elasticities from the specification with gravity controls. ${ }^{10}$

\section{Figure 1: Variance Decomposition of Tariffs Across Sectors}

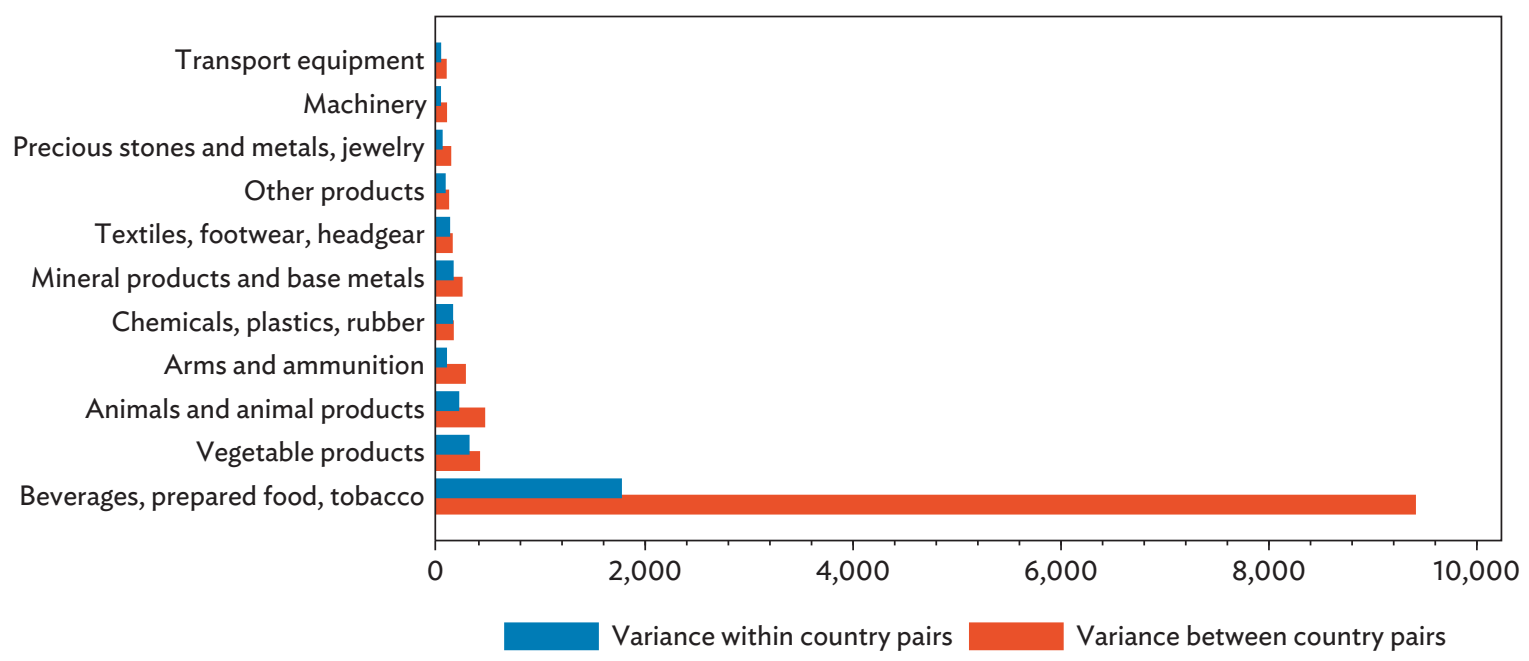

Note: Sectors correspond to an ad hoc aggregation of sections in the Harmonized System (HS) and are ranked by total variance. Variance is computed at the sector level by averaging across HS chapters.

Source: Authors' calculations.

10 The elasticities estimated with both specifications are available at: https://sites.google.com/site/juleshugot/research. 


\section{Residual endogeneity}

The bilateral effects control for endogeneity arising from time-invariant pair-specific features, but a possibility remains that time-varying bilateral factors correlated with tariffs also affect bilateral trade. Nontariff barriers would be the most obvious such factor. However, they often apply to all partners - such as labeling requirements - and would largely be absorbed by the country-year effects.

The nontariff barriers that could be sources of endogeneity are those that vary across both country pairs and time. This could include measures that are positively correlated with tariffs. For example, when a tariff cannot be raised further, a government might resort to raising nontariff barriers instead. Nontariff barriers could also be negatively correlated with tariffs. For example, a government might raise nontariff barriers to protect an industry from increased competition arising from an FTA. A positive (negative) correlation between nontariff barriers and tariffs would result in an upward (downward) bias in the estimated trade elasticities.

\section{Step 2: Counterfactual Simulations}

The second step of the partial equilibrium tool combines the tariff scenarios with the trade elasticities to generate counterfactuals and quantify the trade impact of each scenario.

Let superscripts 0 and CF denote baseline and counterfactual variables. For baseline and counterfactual trade, equation 5 respectively writes:

$$
\begin{aligned}
& \mathrm{X}_{i j t}^{0}=\exp \left[\begin{array}{c}
\varepsilon \times \ln \left(\text { Tariff }_{i j t}^{0}\right)+\gamma_{1} \times \mathrm{CU}_{i j t}^{0}+\gamma_{2} \times \operatorname{Conti}_{i j}+\gamma_{3} \\
\times \operatorname{Coml}_{i j}+\gamma_{4} \times \operatorname{Colo}_{i j}+\gamma_{5} \times \ln \left(\text { Dist }_{i j}\right)+\pi_{i t}+\chi_{j t}
\end{array}\right] \times \varepsilon_{i j t}, \text { and } \\
& \mathrm{X}_{i j t}^{\mathrm{CF}}=\exp \left[\begin{array}{c}
\varepsilon \times \ln \left(\text { Tariff }_{i j t}^{\mathrm{CF}}\right)+\gamma_{1} \times \mathrm{CU}_{i j t}^{\mathrm{CF}}+\gamma_{2} \times \operatorname{Conti}_{i j}+\gamma_{3} \\
\times \operatorname{Coml}_{i j}+\gamma_{4} \times \operatorname{Colo}_{i j}+\gamma_{5} \times \ln \left(\text { Dist }_{i j}\right)+\pi_{i t}+\chi_{j t}
\end{array}\right] \times \varepsilon_{i j t} .
\end{aligned}
$$

The variables in equations 7 and 8 are either available from the data or the counterfactual scenarios or estimated in the first step.

For Armenia's trade within the EEU, the customs union dummy should switch to one in the counterfactual equation 8 after 2015. However, the coefficient captures an average impact, while EEU members were already particularly integrated before 2015-through FTAs-but more fundamentally as they belonged to the same country (the former Soviet Union) before 1992. Also, the trade impact of customs unions partly captures easier border crossing. This effect is reduced for Armenia as it is landlocked and does not border any other EEU member. Integrating the customs union status in the empirical exercise would thus yield implausibly large impacts for trade between Armenia and its EEU partners. Instead, the customs union dummy is excluded from the counterfactuals, which thus reflect the sole impact of tariff changes. The product-level trade impact of tariff changes writes:

$$
\frac{\mathrm{X}_{i j t}^{C F}}{\mathrm{X}_{i j t}^{0}}=\frac{\exp \left[\varepsilon \times \ln \left(\operatorname{Tariff}_{i j t}^{C F}\right)\right]}{\exp \left[\varepsilon \times \ln \left(\operatorname{Tariff}_{i j t}^{0}\right)\right]} .
$$


The numerator and the denominator of equation 9 are identical when tariff and customs union status both remain the same. This partial equilibrium analysis thus ignores the effects of tariff changes for other partners.

\section{General Equilibrium Tool}

In the structural gravity equation, indirect effects to third partners are channeled through the multilateral resistance terms. For example, a reduction in bilateral tariff between two partners decreases their relative accessibility for other partners.

Assessing these effects requires solving the gravity model. But given the nonlinearities introduced by the multilateral resistance terms, it cannot be solved analytically. Instead, the general equilibrium tool relies upon the method implemented by Baier, Yotov, and Zylkin (2019) through the ge_gravity Stata command and inspired by Head and Mayer (2014). The method implements a fixedpoint algorithm to find fixed points for the multilateral resistance terms. It then iterates until the parameters stop changing.

To calculate trade reallocation across partners-but also with self-the method also requires data on domestic production. This data, however, is not available at the product level. ${ }^{11}$ Instead, aggregate data is used for domestic production, bilateral trade, and tariffs. ${ }^{12}$ Also, the domestic production data is limited to manufacturing. For commodity-dependent economies, the general equilibrium tool might therefore underestimate the impact of tariff changes. Lastly, the product-level trade elasticities from the partial equilibrium tool cannot be used. Instead, a single trade elasticity set to -4 is used, which is standard in the trade literature. ${ }^{13}$

The last step consists of computing the impact of trade changes on welfare, as measured by real income. For this, the approach in this paper relies on ACR (2012), who show that in a wide class of micro-founded trade models leading to structural gravity equations, change in welfare $(\widehat{W})$ can be expressed from two sufficient statistics: changes in the share of expenditure on domestic goods $(\hat{\lambda})$ and the trade elasticity $(\varepsilon)$ :

$$
\widehat{W}=\hat{\lambda}^{\frac{1}{\varepsilon}}
$$

To obtain the counterfactual share of expenditure on domestic goods and thus calculate $\hat{\lambda}$, the procedure proposed by Baier, Yotov, and Zylkin (2019) is used. Their method solves numerically for the general equilibrium effects of changes in trade policies by imposing market clearing on the gravity equation. Their routine is also implemented via ge_gravity.

\section{Data}

Bilateral trade. Bilateral product-level trade data is from the $\mathrm{BACl}$ database (CEPII 2021), which reconciles mirror trade flows reported by exporters and importers in the United Nations Comtrade

11 Data is available at the sector level, but it is often not reliable as subtracting exports from output results in negative domestic consumption for many observations.

12 Tariffs are aggregated by averaging across products.

13 Head and Mayer (2014) find a median elasticity of -3.78 in their meta-study of structural gravity estimates of the trade elasticity. Simonovska and Waugh (2014) find an elasticity of -4.14 . 
database (UN 2021). ${ }^{14} \mathrm{BACl}$ reports data in US dollars for 5,020 products, defined using the 1992 version of the $\mathrm{HS}$ 6-digit classification. Missing values are set to zero as $\mathrm{BACl}$ only reports trade exceeding $\$ 1,000$. Finally, $\mathrm{BACl}$ reports trade flows as "free on board", i.e., excluding freight, insurance costs, and tariffs.

Bilateral tariffs. Bilateral HS 6-digit level tariffs are from the Trade Analysis Information System database (TRAINS) (UNCTAD 2021). TRAINS converts most non-ad valorem tariffs to ad valorem equivalents. ${ }^{15}$ Tariffs are set to the minimum of the resulting ad valorem MFN or preferential tariff and converted to the 1992 version of the HS classification for matching with trade flows.

Domestic trade. Domestic manufacturing trade is computed as manufacturing output minus exports. Domestic output data is from the Industrial Statistics database, which reports output at the 2-digit industry level using the International Standard Industrial Classification Revision 3 classification (UNIDO 2021). This data only covers manufacturing (codes 15-37), notably excluding agriculture and mining.

Customs unions. Data on customs unions is from the Economic Integration Agreements database (Baier, Bergstrand, and Feng 2014). The latest version (2017) reports trade agreements in force in all years from 1950 to 2012, classified across the depth of these agreements, including customs unions. ${ }^{16}$

\section{Commission.}

EEU common external tariff. Data on the EEU CET was provided by the Eurasian Economic

Gravity dummies. Data on contiguity, common language (spoken by at least $9 \%$ of the population), colonial relationship post-1945, and population-weighted bilateral distances are from the CEPII's Gravity database (Head, Mayer, and Ries 2010).

Sample coverage for the partial equilibrium tool. The final dataset includes available data for a set of 100 economies, including the pairs they form with any partner. ${ }^{17}$ These 100 economies account for $99.5 \%$ of Armenia's total trade. Trade flows are matched with tariffs for $96.8 \%$ of Armenia's trade.

$14 \mathrm{BACl}$ attributes a weight to each reporter capturing its reliability. This weight increases with the proximity of a country's reporting to the reporting of its partners for the same flows.

15 An ad valorem tariff is set as a percentage of the price. The methodology to compute ad valorem equivalents covers specific tariffs (per unit), compound tariffs (combination of ad valorem and specific), and mixed tariffs (either ad valorem or specific, depending on certain conditions) (Stawowy 2021).

16 Coverage for this paper extends until 2018, so it is assumed that trade agreements in place in 2012 remained in place. Data were also adjusted to incorporate EEU membership.

17 For example, the data includes trade between Montenegro and Italy, because Italy is among the 100 economies despite Montenegro not being included. The 100 economies include the following ADB developing member economies: Armenia; Azerbaijan; Bangladesh; Georgia; Hong Kong, China; India; Indonesia; Kazakhstan; the Kyrgyz Republic; Malaysia; Myanmar; Pakistan; the Philippines; the PRC; Republic of Korea; Singapore; Tajikistan; Thailand; Turkmenistan; Uzbekistan; and Viet Nam; together with the following economies, identified by their iso 3-digit codes: AGO, ARE, ARG, AUS, AUT, BEL, BGR, BLR, BOL, BRA, CAN, CHE, CHL, CIV, COD, COL, CRI, CYP, CZE, DEU, DNK, DOM, DZA, ECU, EGY, ESP, EST, ETH, FIN, FRA, GBR, GHA, GRC, GTM, HRV, HUN, IRL, IRN, IRQ, ISR, ITA, JOR, JPN, KEN, KWT, LBN, LTU, LVA, MAC, MAR, MDA, MEX, MLT, NGA, NLD, NOR, NZL, OMN, PAN, PER, POL, PRT, QAT, ROU, RUS, SAU, SRB, SVK, SVN, SWE, SYR, TUR, TZA, UKR, URY, USA, VEN, ZAF. 
Sample coverage for the general equilibrium tool. The general equilibrium tool requires both trade and domestic output data. The sample was restricted to manufacturing as domestic output is only available for manufacturing. Observations are excluded when internal trade (i.e., domestic output minus exports) is negative-possibly due to underreporting of output data. Finally, market clearing requires a balanced dataset where trade flows between each pair of partners are available for all years. The resulting dataset covers 60 economies for 2006-2018, including all EEU members and Armenia's potential FTA partners. These restrictions reduce the coverage to $83 \%$ of Armenia's total trade.

\section{PRODUCT-LEVEL ESTIMATIONS OF THE TRADE ELASTICITY}

This section reports summary results regarding the estimated product-level trade elasticities.

\section{A. Distribution of Estimated Elasticities}

The estimated elasticities for each HS 6-digit product are available online. ${ }^{18}$ Figure 2 shows the distribution of all the elasticities estimated through the preferred specification (equation 5 , with gravity controls). The estimations generate 5,014 elasticities, of which $82.4 \%$ are negative, as expected. Out of these, $73.7 \%$ are significant at the $10 \%$ level, $64.8 \%$ at the $5 \%$ level, and $49.9 \%$ at the $1 \%$ level. ${ }^{19}$ The distribution of elasticities across levels of significance are broadly similar, although they tend to be more distant from zero at higher levels of confidence (Figure 3).

The elasticities which are negative and significant at the $10 \%$ level range from -151 to -0.7 . The median negative-significant elasticity is -7.0 . This range broadly compares with those from Caliendo and Parro (2015) (-69.3 to -0.5) and FGO (2019) (-131.8 to -0.1).

The distribution of elasticities varies across sectors. Elasticities are the largest for commodities such as precious stones and metals, and chemicals (Figure 4). This is consistent with suppliers for these products being easily replaced. Conversely, elasticities tend to be small for distinctive products such as foodstuffs and beverages.

The spreadsheets also provide the elasticities obtained through equation 6, with country-pair fixed effects. As it only relies on the variance of tariffs across time, this specification results in fewer significant elasticities. The paper obtains 4,942 elasticities, of which $65.0 \%$ are negative. Out of these, $58.1 \%$ are significant at the $10 \%$ level, $44.8 \%$ at the $5 \%$ level, and $25.1 \%$ at the $1 \%$ level. Interestingly, the distribution of these elasticities is shifted to the right, closer to zero (Figure 5). The median negative-significant elasticity is -3.3 , less than half its counterpart from the specification with gravity controls. This suggests that unobserved trade costs-those not controlled for in the specification with gravity controls-are positively correlated with tariffs, biasing the elasticities with gravity controls downwards.

\footnotetext{
18 See "Trade elasticities estimated with gravity controls" and "Trade elasticities estimated with pair fixed effects" spreadsheets at https://sites.google.com/site/juleshugot/research.

19 The corresponding shares in FGO (2019) are: $78 \%$ at the $10 \%$ level, $72 \%$ at $5 \%, 61 \%$ at $1 \%$.
} 
Figure 2: Distribution of Estimated Trade Elasticities

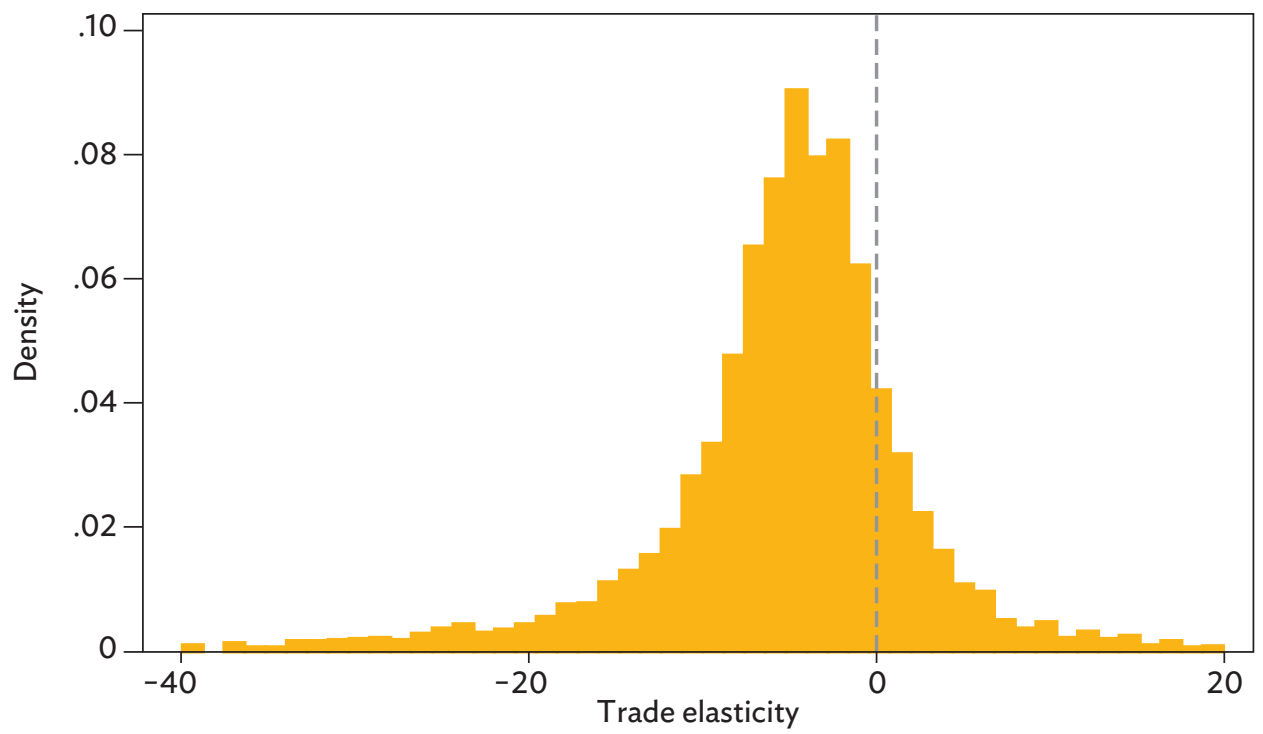

Note: The distribution is trimmed below -40 and above 20

Source: Authors' calculations.

Figure 3: Distribution of Estimated Trade Elasticities Across Levels of Confidence

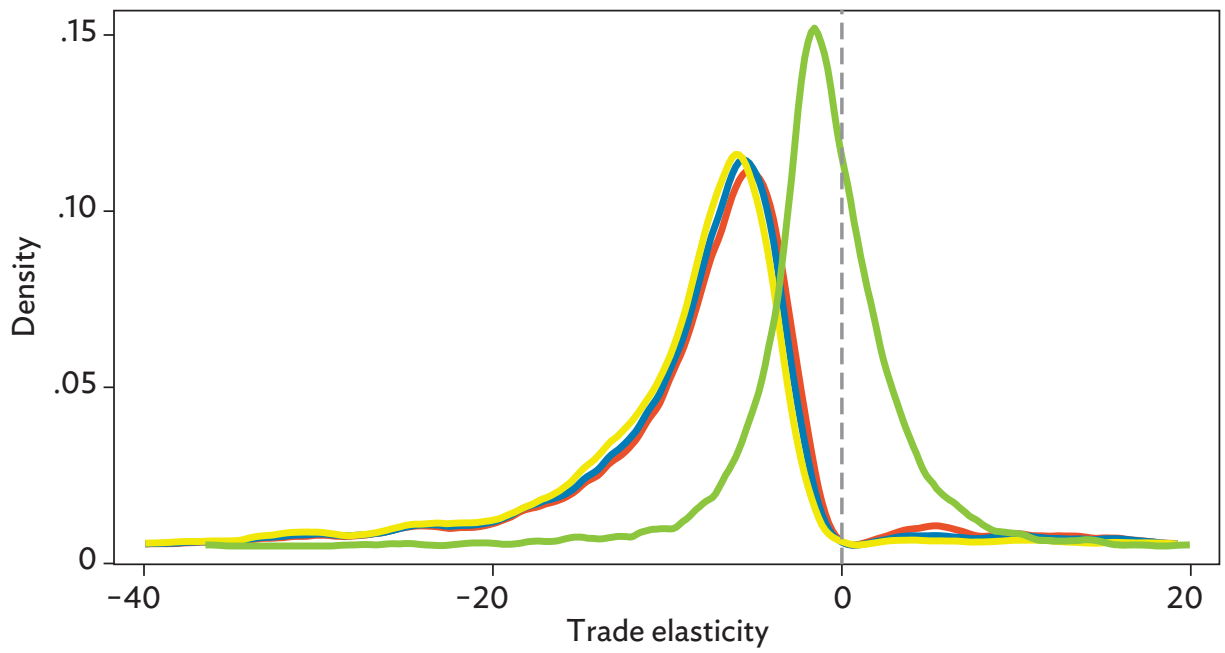

- Significant at $10 \%$ level _ Significant at $5 \%$ level - Significant at $1 \%$ level — Nonsignificant

Note: Kernel density estimates of the density functions. The distributions for the significant elasticities include all elasticities that are at least significant at the level indicated. The distribution for the nonsignificant elasticities includes the elasticities that are not significant at the $10 \%$ level.

Source: Authors' calculations. 
Positive-significant elasticities account for $4.0 \%$ of the elasticities obtained with gravity controls, and $8.7 \%$ of those from the pair fixed-effect specification. These elasticities, however, concentrate in sectors where market forces are not the main driver of trade-including luxury goods such as pearls and watches-or in sectors where supply is concentrated, such as rare metals used in the aerospace and nuclear industries. Tariff changes for products with positive or nonsignificant elasticities are assumed to have no impact on trade in the partial equilibrium tool.

\section{B. Customs Union Effect}

Controlling for customs unions avoids that the tariff elasticities reflect the lower nontariff barriers associated with customs unions. The median estimate for the customs union dummy is 0.8 , which translates into a $123 \%$ boost to trade for the median products, beyond the effect through tariff reductions (Figure 6). Other control variables also have the expected sign and magnitude for most products.

Figure 4: Distribution of Trade Elasticities Significant at the 10\% Level, Across Sectors

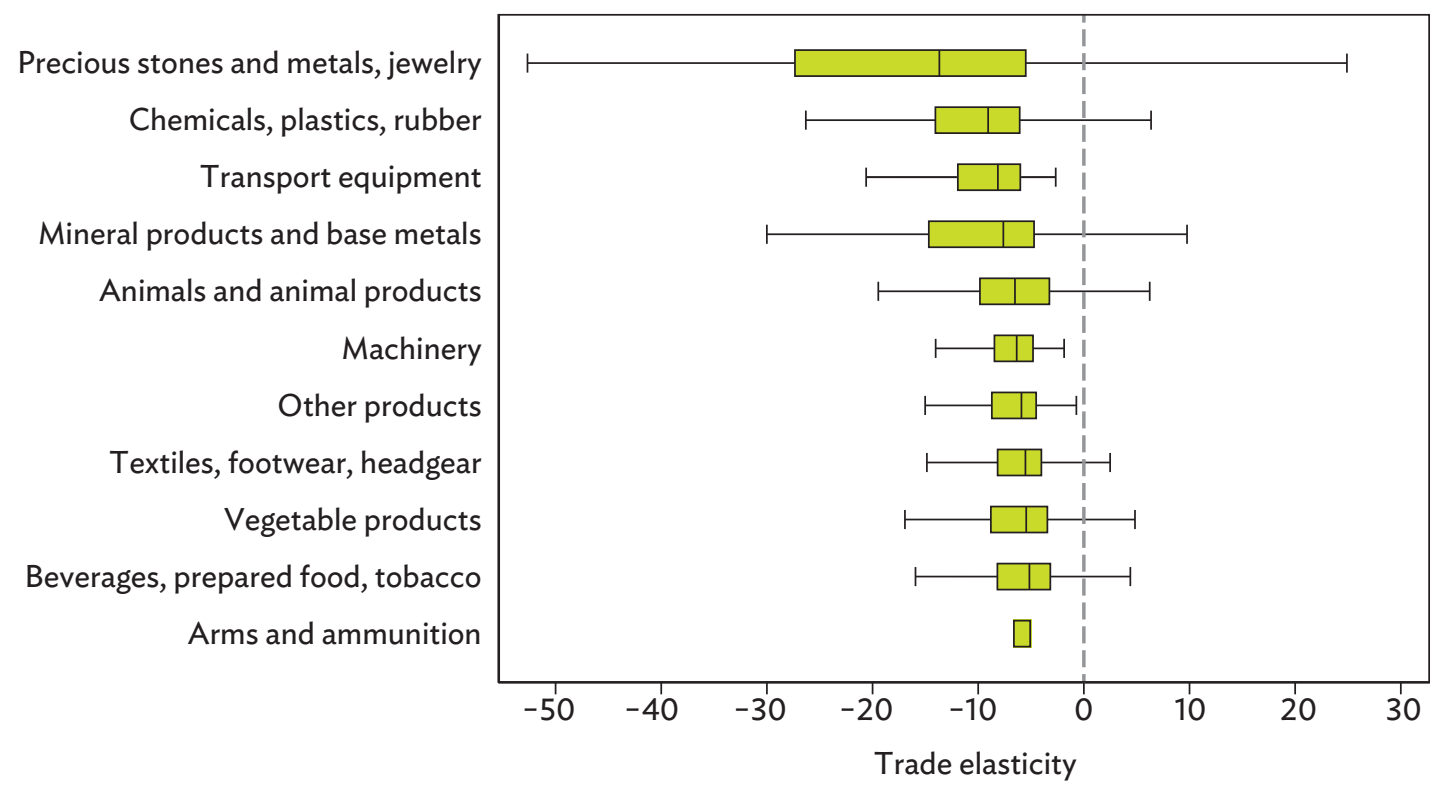

Note: Sectors correspond to an ad hoc aggregation of sections in the Harmonized System and are ranked from the largest to the smallest (negative) median trade elasticity.

Source: Authors' calculations. 
Figure 5: Distribution of Negative and Significant Trade Elasticities: Gravity Controls and Pair Fixed Effects Specifications

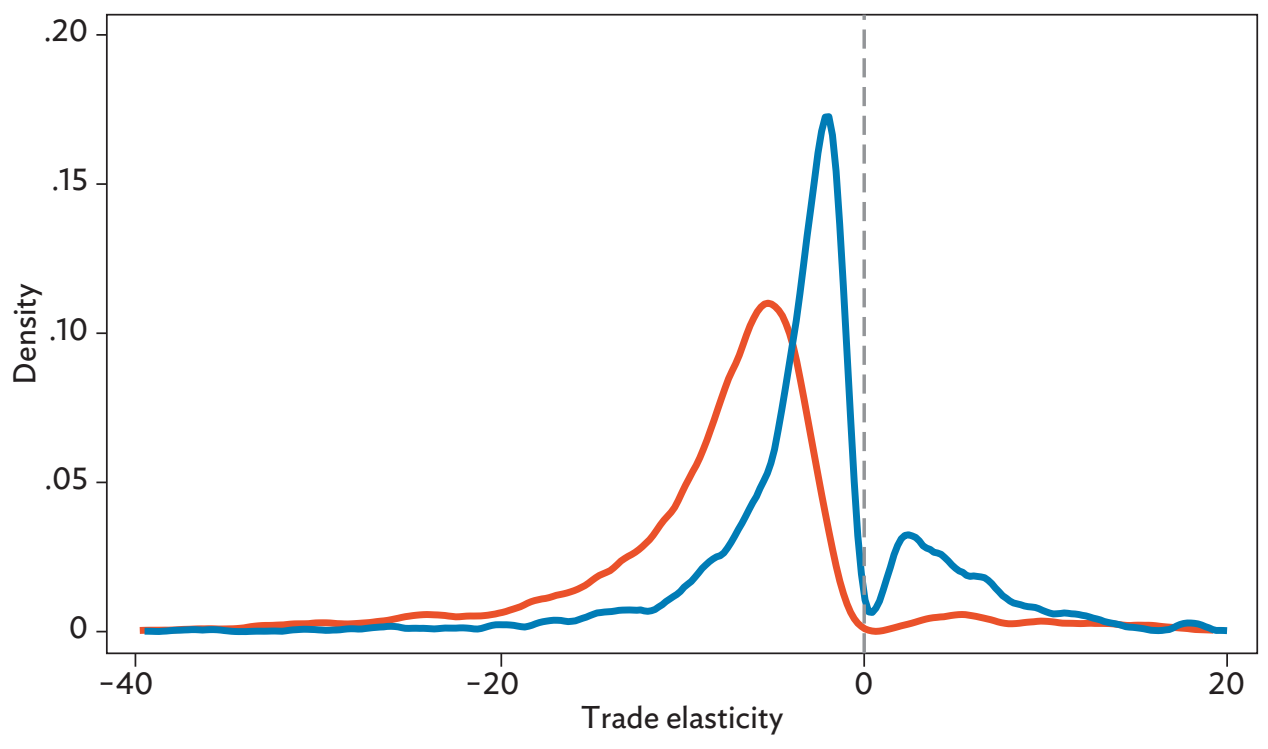

- Specification with gravity controls - Specification with pair fixed effects

Note: Kernel density estimates of the density functions.

Source: Authors' calculations.

Figure 6: Distribution of Customs Union Coefficients

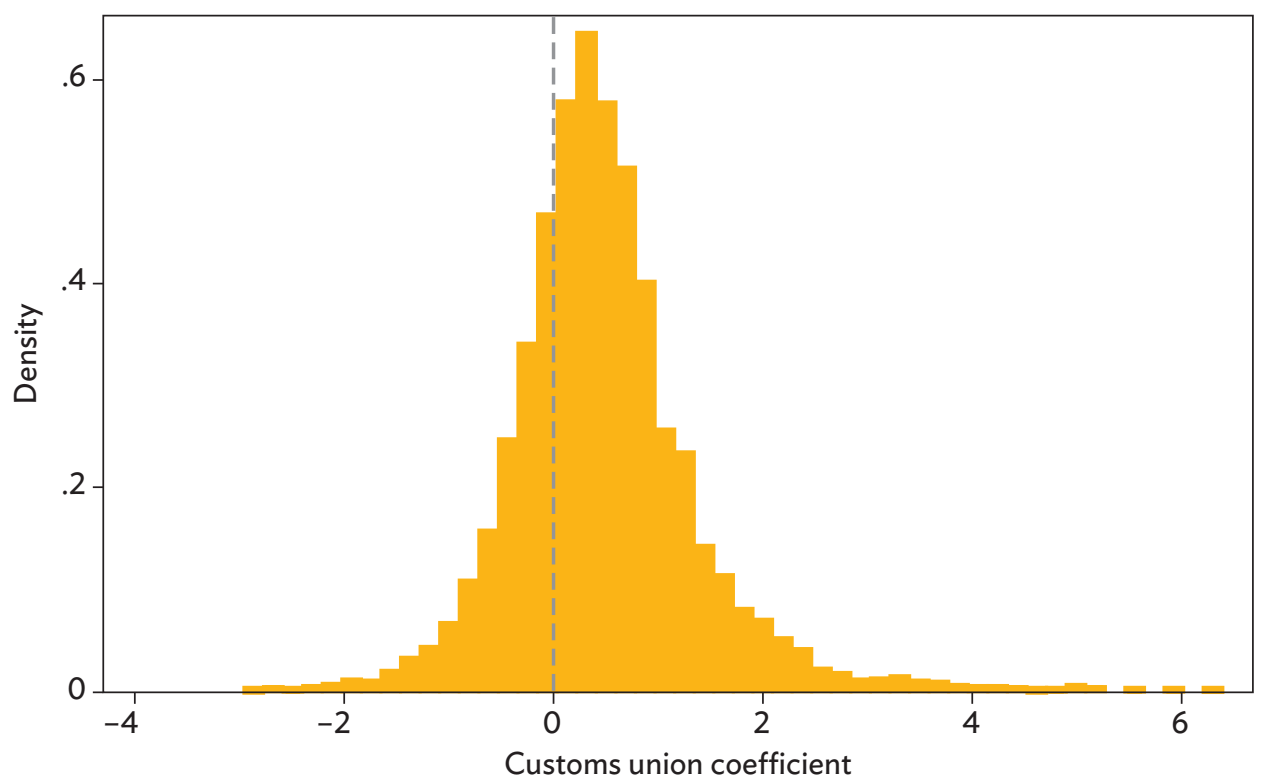

Note: The distribution is trimmed below -5 and above 10 .

Source: Authors' calculations. 


\section{Coverage for Armenia}

Figure 7 shows that the trade elasticities from the gravity-controls specification have covered close to $60 \%$ of Armenia's trade since 2007, about twice the share covered by the elasticities from the pair fixed-effects specification. Figure 8 shows that the coverage is good for certain sectors such as chemicals and plastics, metals, or transportation, but is limited for foodstuffs, minerals, and "other".

\section{Figure 7: Coverage of Armenia's Trade by Negative-Significant Trade Elasticities: Gravity-Controls and Pair Fixed Effects Specifications}

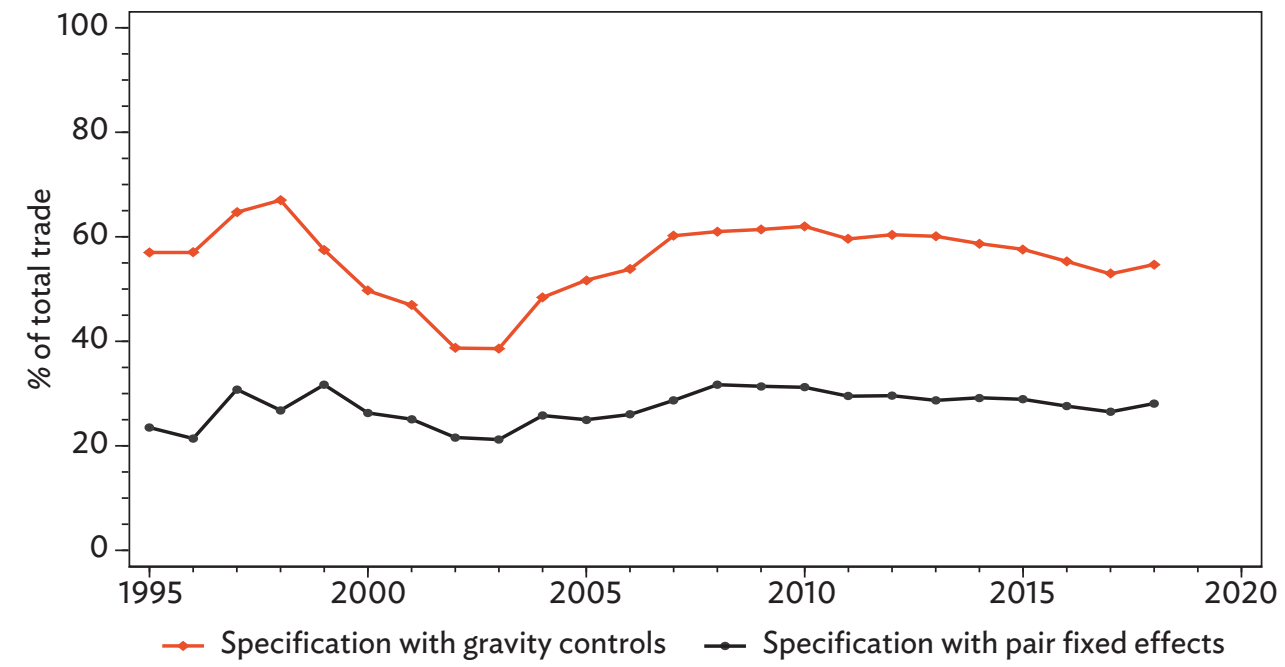

Source: Authors' calculations.

Figure 8: Armenia's Trade During 1995-2018 Covered by Negative-Significant Trade Elasticities

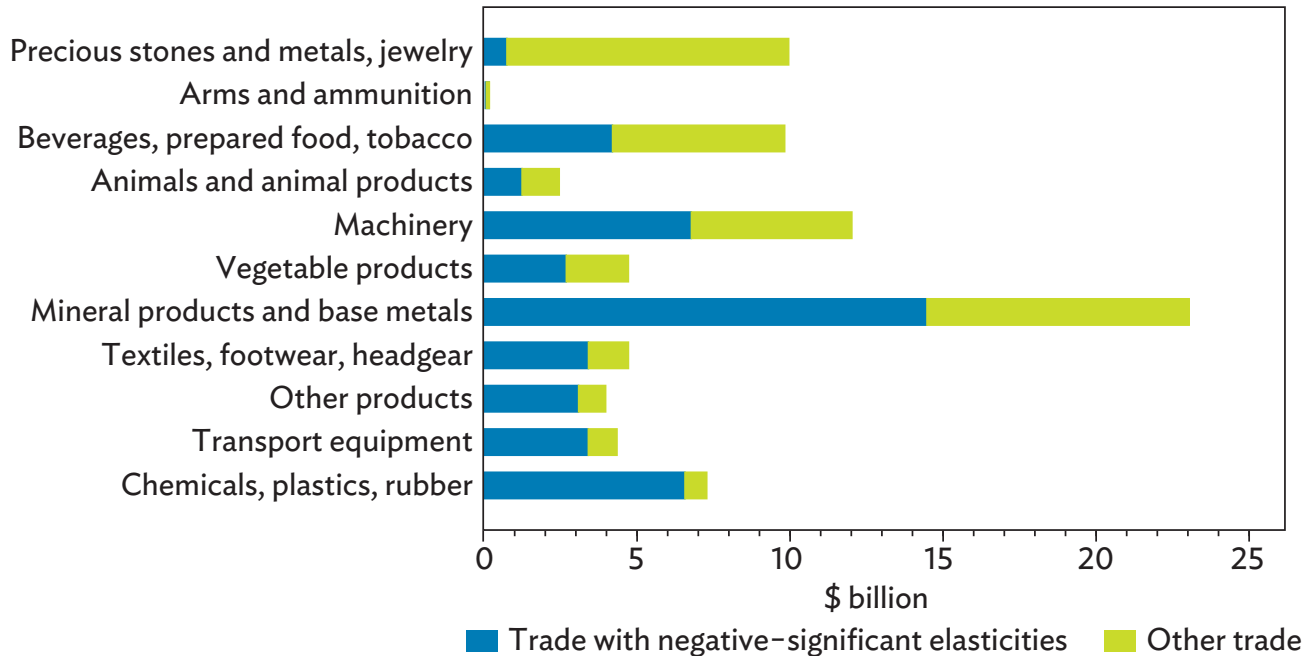

Note: Results from the specification with gravity controls. The significance threshold is set at $5 \%$. Sectors correspond to an ad hoc aggregation of sections in the Harmonized System and are ranked from the smallest to the largest share of trade covered by negative-significant elasticities.

Source: Authors' calculations. 


\section{CHANGES IN ARMENIA'S TARIFFS}

This section presents stylized facts regarding recent changes affecting Armenia's tariffs.

\section{A. Eurasian Economic Union}

The EEU was created on 1 January 2015, and included Belarus, Kazakhstan, and the Russian Federation. Armenia became a member on 2 January 2015 and the Kyrgyz Republic on 6 August 2015. The EEU is an economic union, i.e. a form of deep economic integration that combines customs unions and a common market. As a customs union, the EEU involves duty-free trade among members, a common external tariff, and common regulation to allow the entry of products.

The EEU builds upon the customs union of Belarus, Kazakhstan, and the Russian Federation, which had been in force since $2010 .{ }^{20}$ Isakova, Koczan, and Plekhanov (2016) analyze the early impact (2009-2010) of the customs union and find statistically significant negative effects-although modest in magnitude-on Kazakhstan's imports from the PRC. They conclude that tariff barriers might be less important than expected and suggest that the lowering of nontariff barriers within the EEU could bring net trade benefits from membership. Gnutzmann and Gnutzmann-Mkrtchyan (2020) examine the trade impact of the customs union before the creation of the EEU and isolate tariffs from nontariff impacts. They find that it led to a 35\% increase in trade within the customs union relative to external partners, with $20 \%$ due to tariff increases for outside partners and $15 \%$ to lower nontariff barriers within the customs union.

Armenia initially received exemptions from the CET for 772 products. These products account for $6.3 \%$ of tariff lines but 38\% of Armenia's imports from outside the EEU (WTO 2018). These exemptions were justified by Armenia's low tariffs before joining the EEU. A transition schedule specifies the pace of the convergence until January 2022. Most tariff changes took place in January 2015, but changes also occurred in succeeding years, particularly on 1 January 2020 (Figure 9). ${ }^{21}$ Tariff increases due to the convergence process affected mostly vehicles in 2020, pharmaceuticals and textiles in 2021, and live animals in 2022. Further complexity in the convergence process comes from changes in the CET itself. These changes notably enable the Russian Federation to comply with commitments made to lower its tariffs upon its WTO accession in 2012.

The largest changes in tariffs took place in 2015 as the average tariff increased from $3.7 \%$ to 7.0\% (Figure 10). ${ }^{22}$ Armenia's average tariff then decreased in 2016-2017 as the EEU CET converged to the bound tariffs the Russian Federation committed to in the framework of the WTO, but it increased again in 2018 as tariffs further converged to the CET. The trade-weighted average tariff did not increase as much as the simple average until 2017 as the largest tariff increases hit products with low imports in Armenia. The trade-weighted average tariff got closer to the simple average tariff in 2018 as Armenia's tariff continued alignment with the EEU CET.

20 See Vinokurov (2017) for a detailed overview of the EEU timeline.

21 See WTO (2018) for a detailed discussion on Armenia's exceptions and convergence to CET.

22 Average tariffs are calculated across the tariff lines for which Armenia records imports for at least one year in 2008-2017. 

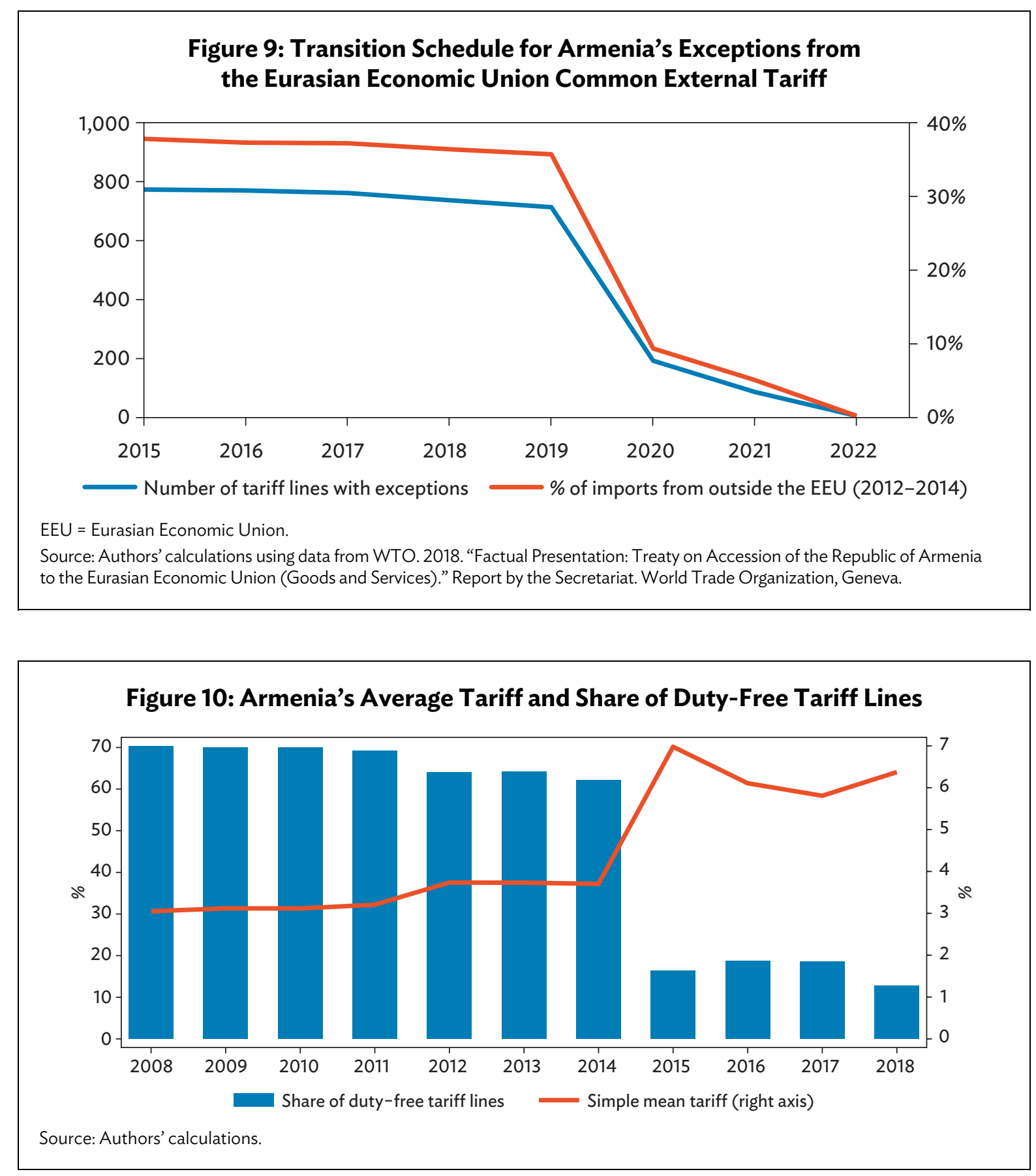

The EEU CET has also made Armenia's tariff structure more complex. The share of duty-free tariff lines fell from $62 \%$ to $17 \%$ with the EEU accession. While $99.6 \%$ of tariffs were either $0 \%$ or $10 \%$ before 2015 , they take many more values as of 2022, with tariff peaks at $0 \%, 5 \%, 10 \%$, and $15 \%$ (Figure 11).

The convergence to the EEU CET affects product categories differently (Figure 12). Tariff increases for animal and animal products, arms and ammunition, and "precious stones and metals, jewelry" are particularly striking. On the other hand, tariffs declined for vegetables, footwear, and machinery. 

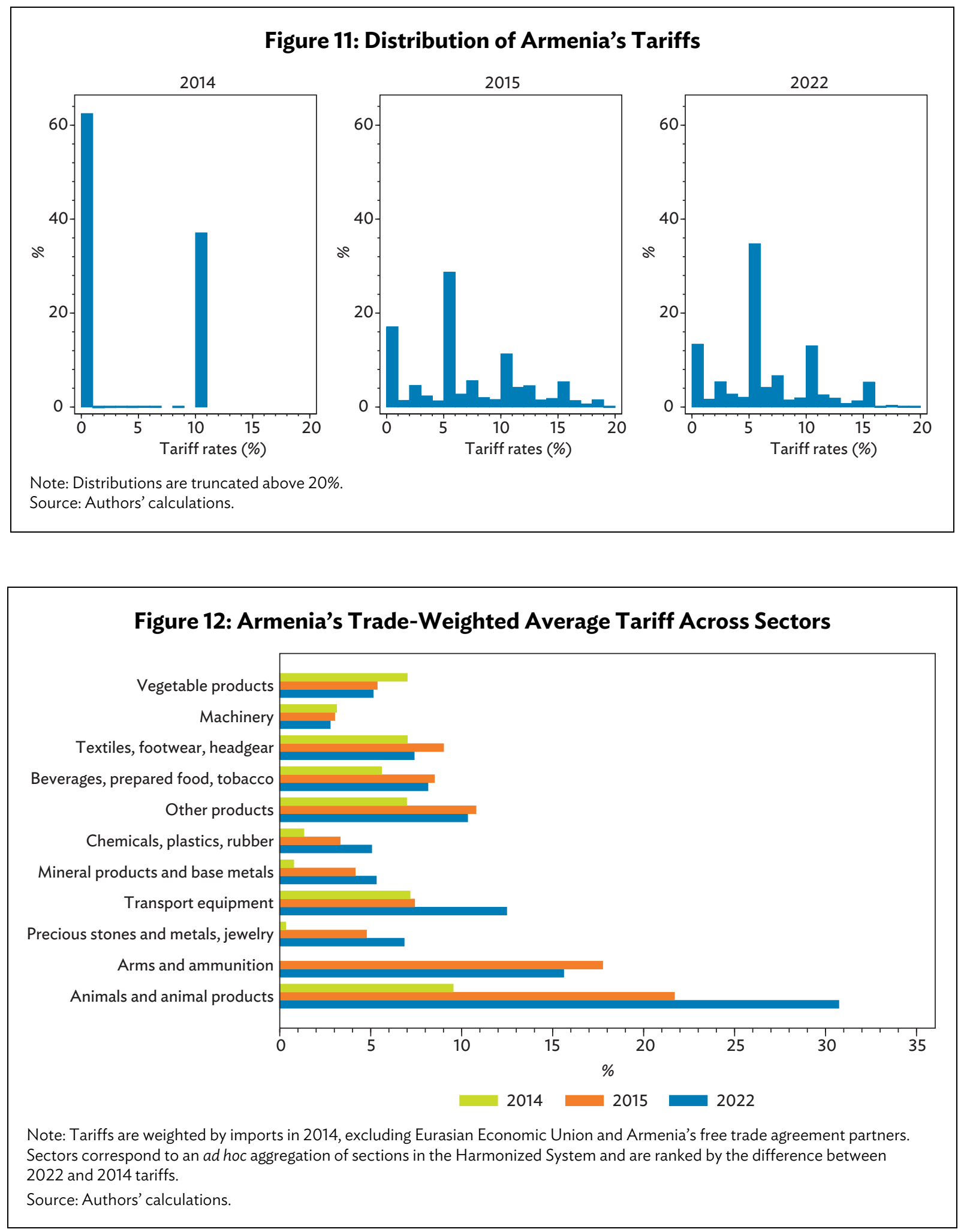


\section{B. Other Trade Agreements Affecting Armenia}

Armenia had FTAs in place with all EEU members before 2015 (Table 4). This included bilateral FTAs with Belarus, Kazakhstan, the Kyrgyz Republic, and the Commonwealth of Independent States FTA which ensured free trade with the Russian Federation. These FTAs were superseded by the EEU.

The FTAs with other countries in force before EEU accession remain in place as permitted by the EEU Treaty. This enables Armenia to maintain duty-free trade with Georgia, Moldova, Tajikistan, Turkmenistan, and Ukraine.

Armenia and the EU signed the Comprehensive and Enhanced Partnership Agreement on 24 November 2017, and some chapters have been applied since 1 June 2018. The agreement aims to strengthen cooperation but does not involve preferential tariffs. This makes it significantly different from the deep and comprehensive free trade agreements signed by the EU with Georgia, Moldova, and Ukraine.

Besides being a beneficiary of the EU's GSP+ scheme until 31 December 2021, Armenia also benefits from the GSP programs provided by Canada, Japan, Norway, Switzerland, and the US.

Table 4: Free Trade Agreements Involving Armenia

\begin{tabular}{ll}
\hline Free Trade Agreement & Date of Entry Into Force \\
\hline FTAs remaining in place after EEU accession & 20 July 1994 \\
\hline Armenia - Tajikistan & 21 December 1995 \\
Armenia - Moldova & 7 July 1996 \\
Armenia - Turkmenistan & 18 December 1996 \\
Armenia - Ukraine & 11 November 1998 \\
Armenia - Georgia & 27 October 1995 \\
\hline FTAs terminated upon EEU accession & 3 January 2002 \\
\hline Armenia - Kyrgyz Republic & 28 July 2003 \\
Armenia - Kazakhstan & 17 October 2012 \\
\hline Armenia - Belarus & Commonwealth of Independent States FTA (Armenia, Belarus, Kazakhstan, Kyrgyz Republic, \\
\hline
\end{tabular}

$\mathrm{EEU}=$ Eurasian Economic Union, $\mathrm{FTA}$ = free trade agreement.

Source: WTO. 2018. "Factual Presentation: Treaty on Accession of the Republic of Armenia to the Eurasian Economic Union (Goods and Services)." Report by the Secretariat. World Trade Organization, Geneva.

\section{Trade Agreements between the Eurasian Economic Union and Other Economies}

The EEU has FTAs with Viet Nam (since October 2016), and with Serbia (since July 2021). It also signed an FTA with Singapore in 2019, but the agreement is not yet in force. The EEU is also negotiating FTAs with Egypt, India, and Israel and has initiated discussions with Bangladesh, Cambodia, Chile, Ecuador, Indonesia, Jordan, Mongolia, Peru, the Republic of Korea, and Thailand. 
The empirical section assesses the impact of hypothetical FTAs that the EEU might sign with Iran and the PRC. With Iran, an interim agreement came into force in October 2019 for 3 years, during which negotiations for an FTA are conducted. This interim agreement reduces tariffs for $4 \%$ of tariff lines but does not eliminate them. ${ }^{23} \mathrm{~A}$ Trade and Economic Cooperation Agreement with the PRC came into force in October 2019. This agreement increases the transparency of regulations and simplifies trade procedures, but does not lower tariffs.

Although EEU membership increases tariffs on imports from other economies, it may also create new trading opportunities for Armenia. From the point of view of potential FTA partners, a trading bloc such as the EEU is more attractive than a small economy like Armenia for negotiating an FTA. The larger market size of the EEU can also increase bargaining power in FTA negotiations. Estimations of the impact of potential FTAs with Iran and the PRC contribute to assessing these impacts.

\section{IMPACT OF TARIFF CHANGES ON ARMENIA}

This section reports the estimated impact of three actual or potential series of tariff changes affecting Armenia. These scenarios include (i) the full convergence to the EEU CET by 1 January 2022, (ii) FTAs between the EEU and Iran, and between the EEU and the PRC, and (iii) the loss of eligibility to the EU's GSP and GSP+ preferential tariff schemes.

This empirical section reports general equilibrium results (aggregated across products and limited to manufacturing) and partial equilibrium results (product-level detail). For the partial equilibrium tool, tariff changes are assumed to have no impact on trade if the tariff elasticity is not significant at the $5 \%$ level.

The changes are computed using baseline data for 2018-the last year for which all the required data is available. For the EEU CET convergence scenario, this means that both pre-treatment trade (in 2014) and post-treatment trade (in 2022) are computed using equations 7 and 8. The trade impact is thus the difference between two counterfactual scenarios, both based on trade patterns as of 2018.

For the two FTA scenarios, the impacts are estimated assuming duty-free trade for all goods. The scenario for the EEU-Iran FTA thus goes beyond the interim agreement already in place. For the last scenario (loss of EU GSP and GSP+ eligibility), EU tariffs imposed on Armenia's exports are assumed to revert to the MFN level as of 2018.

\section{A. Convergence to the Eurasian Economic Union Common External Tariff}

\section{General Equilibrium Welfare and Trade Impact}

Results suggest that the convergence to the EEU CET will decrease Armenia's welfare by $1.6 \%$ (Figure 13). The largest impact comes from the tariff changes that occurred before $2019(-1.42 \%)$.

\footnotetext{
23 Annex 1 of the interim agreement specifies tariff reductions by the EEU for 502 tariff lines and by Iran for 360 tariff lines.
} 
The tariff changes of January 2021 also had a negative impact-although more moderate $(-0.11 \%)$ - while the changes that occurred in 2020 and 2022 are expected to have minimal impacts.

As converging to the EEU CET requires increases to most tariffs, it is estimated that there will be a decrease in manufacturing imports from outside the EEU and Armenia FTA partners by $\$ 145$ million. This decrease, however, is expected to be partially compensated by a $\$ 92$ million increase in manufacturing imports from EEU and FTA partners: this is the trade reallocation effect. Convergence to the EEU CET is thus expected to result in a $\$ 54$ million net decline in manufacturing imports, which constitutes $1.5 \%$ of manufactured imports. As for welfare, most of the trade impact is driven by the tariff changes that occurred in 2019, and particularly in 2015.

In terms of partners, manufacturing imports from the EU are expected to decrease by $\$ 59$ million, followed by the PRC ( $\$ 27$ million), and Turkey ( $\$ 16$ million) (Figure 14). The beneficiaries from import reallocation are expected to be the Russian Federation ( $\$ 73$ million), and Ukraine ( $\$ 12$ million).

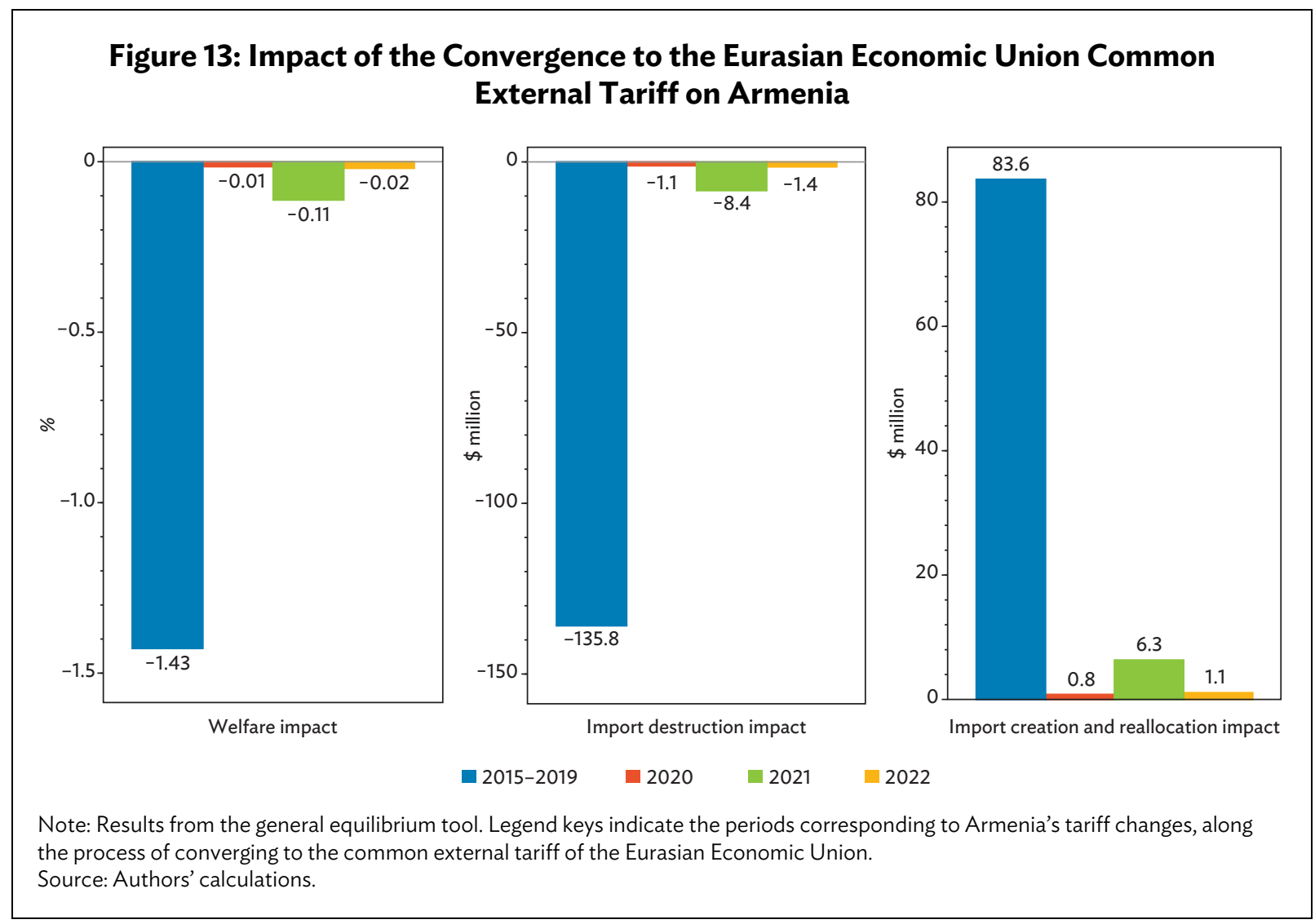




\section{Figure 14: Impact of the Convergence to the Eurasian Economic Union Common External Tariff on Armenia's Imports, by Partner}
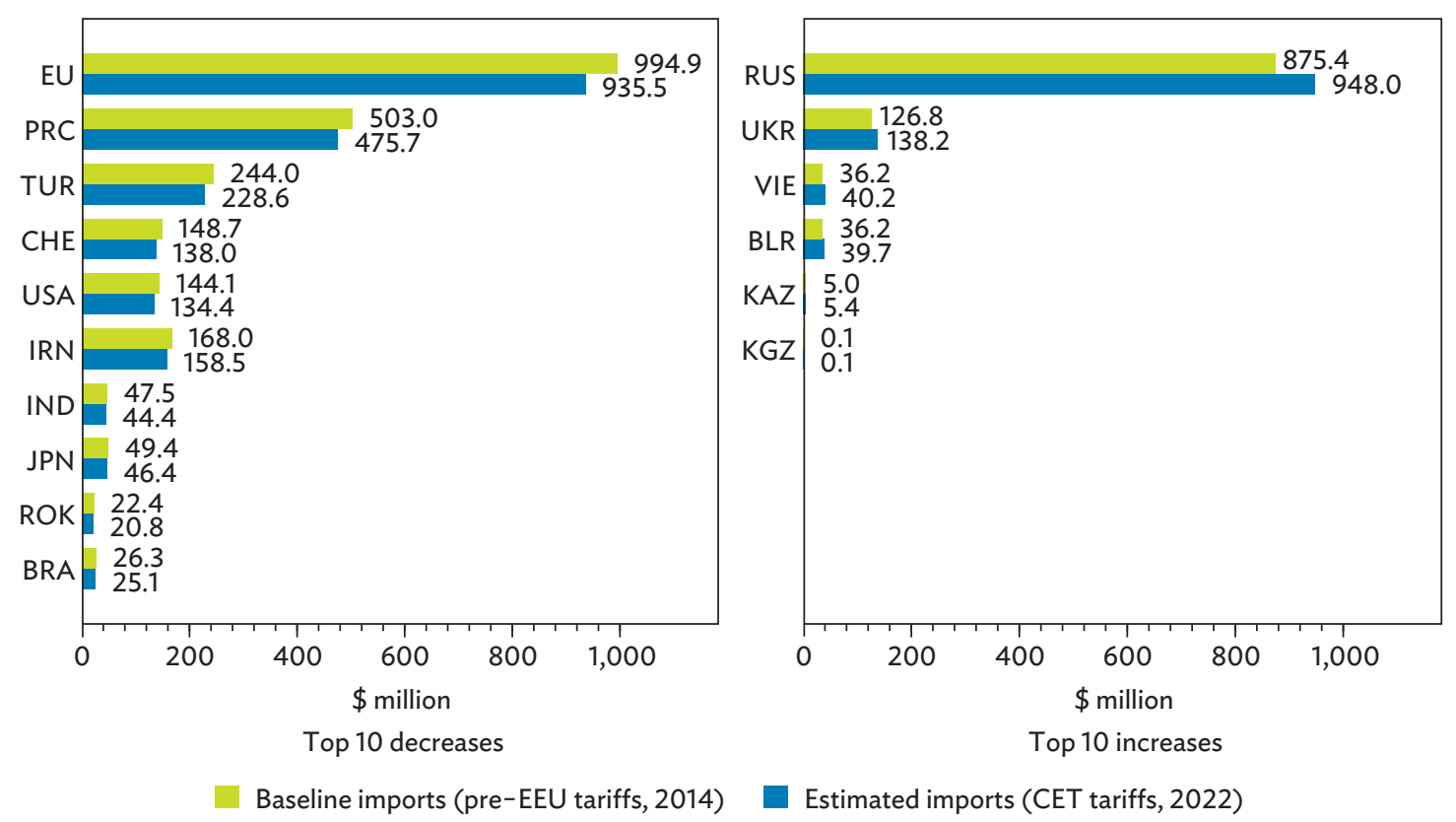

$\mathrm{BRA}=$ Brazil, $\mathrm{CET}=$ common external tariff, $\mathrm{CHE}=$ Switzerland, $\mathrm{EEU}=$ Eurasian Economic Union, $\mathrm{EU}=$ European Union, $\mathrm{IND}=$ India, IRN = Iran, JPN = Japan, KAZ = Kazakhstan, KGZ = Kyrgyz Republic, PRC = People's Republic of China, ROK = Republic of Korea, TUR $=$ Turkey, USA = United States, RUS = Russian Federation, UKR = Ukraine, VIE = Viet Nam.

Note: Results from the general equilibrium tool. The left panel reports the trade impacts for the ten partners with the largest imports reductions.

Source: Authors' calculations.

\section{Partial Equilibrium Impact}

The partial equilibrium impact of convergence to the CET is one order of magnitude higher than the general equilibrium impact at $\$ 592$ million ( $-12 \%$ of Armenia's total imports). This larger impact is due to a combination of factors. First, the general equilibrium analysis is restricted to manufacturing, which only accounts for about two-thirds of Armenia's imports. Second, the general equilibrium tool gauges imports reallocation, which mitigates import reductions from economies other than EEU members and Armenia's other FTA partners. Third, the partial equilibrium tool relies on product-level tariff elasticities, which may magnify the overall trade impact compared to the general equilibrium tool, which relies on a single, moderate elasticity.

Results suggest that imports of chemicals, plastics, and rubber should decline the most, by $\$ 201$ million (-25\%), followed by transport equipment at $\$ 169$ million (-36\%) (Figure 15$)$. Analysis at the product level shows that imports of medicaments should be particularly affected ( $\$ 51$ million), as well as imports of plastics, notably used as containers for food and beverages ( $\$ 28$ million). Imports of prefabricated buildings-including greenhouses-should also fall by $\$ 23$ million (-30\%). Within transport equipment, imports of diesel trucks should fall by $\$ 18$ million ( $-62 \%)$. Imports of television sets, cement, and coffee are expected to increase. These increases arise as tariffs on these products will be lower in 2022 than they were in 2014. These impacts, however, are limited: \$19 million for television sets, $\$ 8$ million for cement, and $\$ 7$ million for coffee. 


\section{Figure 15: Impact of the Convergence to the Eurasian Economic Union Common External Tariff on Armenia's Imports, by Sector}
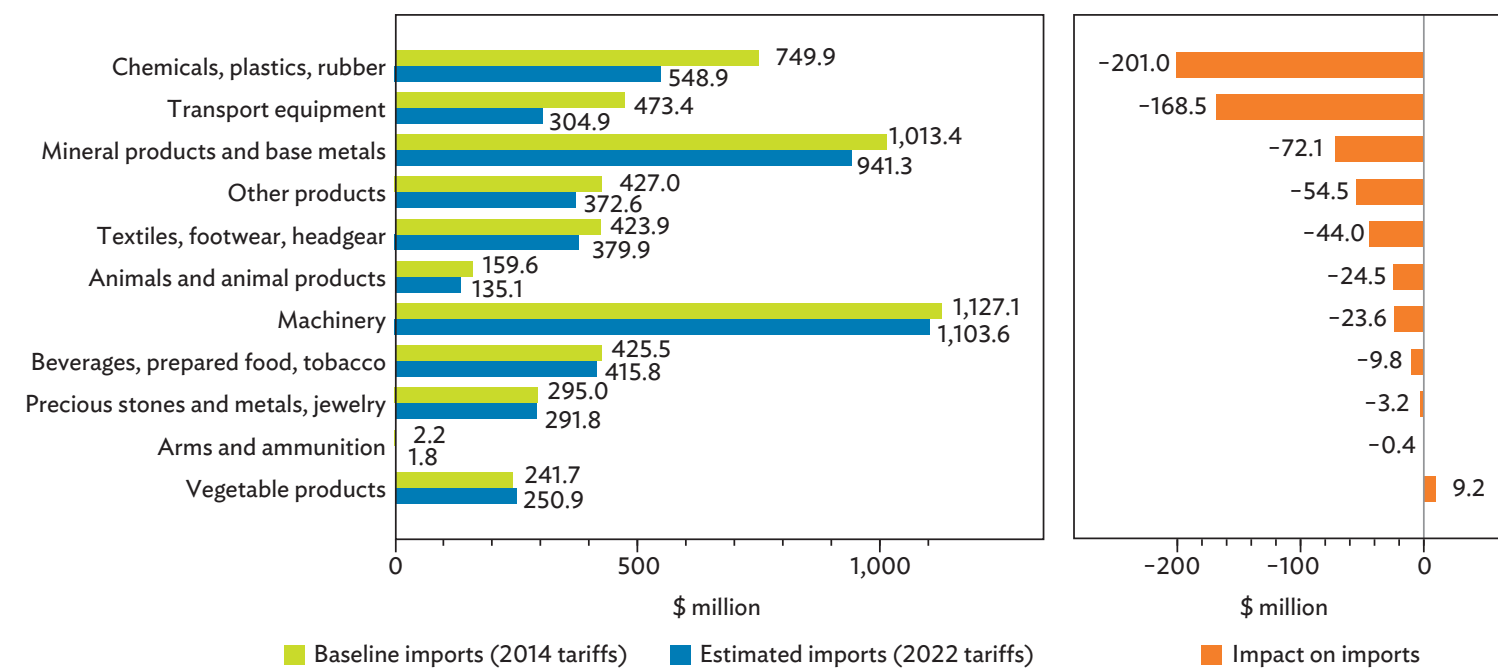

Note: Results from the partial equilibrium tool. Sectors correspond to an ad hoc aggregation of sections in the Harmonized System. Source: Authors' calculations.

\section{B. Free Trade Agreement between the Eurasian Economic Union and Iran}

Armenia runs a trade deficit with Iran, but exports have increased rapidly since 2015 (Figure 16). Mineral products account for $48 \%$ of imports ( $\$ 121$ million), including natural gas ( $\$ 71$ million), cement ( $\$ 21$ million), and crude oil ( $\$ 13$ million). Lamb accounts for $79 \%$ of Armenia's exports to Iran (\$14 million) and has driven the increase of bilateral exports since 2015.

Figure 16: Sector Composition of Armenia-Iran Trade
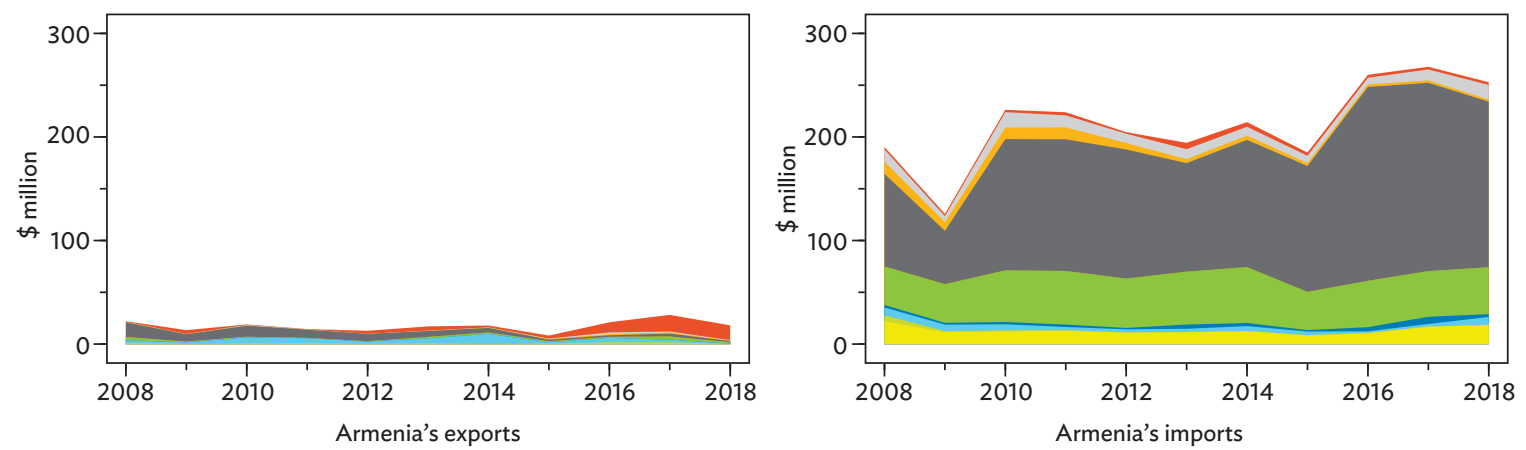

Animals and animal products

Vegetable products

Beverages, prepared food, tobacco

Mineral products and base metals

Precious stones and metals, jewelry

Chemicals, plastics, rubber

Textiles, footwear, headgear

Machinery

Transport equipment

Arms and ammunition

Other products

Note: Sectors correspond to an ad hoc aggregation of sections in the Harmonized System.

Source: Authors' calculations using data from CEPII. BACI Database. http://www.cepii.fr/cepii/en/bdd_modele/presentation.asp?id=37 (accessed 3 March 2021). 


\section{General equilibrium welfare and trade impacts}

The general equilibrium analysis shows that an FTA with Iran would increase Armenia's welfare by $0.3 \%$ (Figure 17). Armenia would reap the largest benefits among EEU members, far ahead of other members. Manufacturing exports to Iran would increase by $\$ 22$ million (26\%), at the expense of a modest reduction of exports to the Russian Federation ( $\$ 2$ million) and the rest of the world ( $\$ 6$ million). Manufacturing imports from Iran would increase by $\$ 42$ million (21\%), also partly at the expense of imports from the Russian Federation ( $\$ 10$ million) and the rest of the world (-\$18 million).

\section{Figure 17: Welfare and Trade Impact of Eurasian Economic Union-Iran Free Trade Agreement, by Partner}

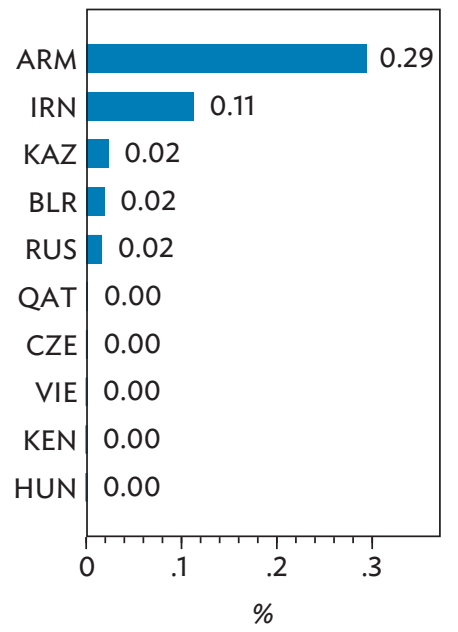

Top 10 welfare impacts

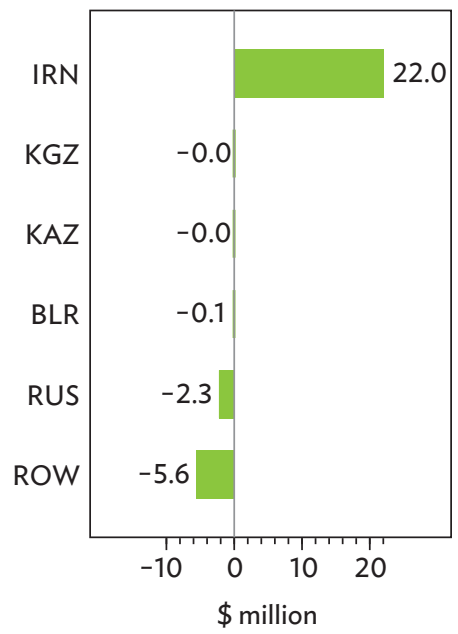

Impact on Armenia's exports

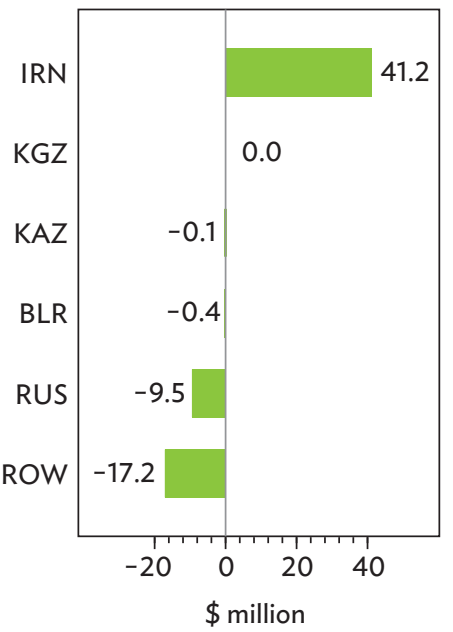

Impact on Armenia's imports

$\mathrm{ARM}=$ Armenia, $\mathrm{BLR}=$ Belarus, $\mathrm{CZE}=$ Czech Republic, $\mathrm{HUN}=$ Hungary, IRN = Iran, $\mathrm{KAZ}=$ Kazakhstan, $\mathrm{KEN}=\mathrm{Kenya}$, KGZ = Kyrgyz Republic, QAT = Qatar, ROW $=$ Rest of the World, RUS $=$ Russian Federation, VIE $=$ Viet Nam.

Note: Results from the general equilibrium tool.

Source: Authors' calculations.

\section{Partial Equilibrium Impact}

The partial equilibrium tool suggests that exports from Armenia to Iran would be multiplied by 2.6, from $\$ 18$ million to $\$ 56$ million. The impact of the convergence to the EEU CET from the partial equilibrium tool is about two times larger than the impact obtained from the general equilibrium tool. Armenia's imports from Iran would increase by $\$ 90$ million (37\%), also about twice the $\$ 42$ million general equilibrium impact.

Armenia's exports would particularly increase for transportation equipment (Figure 18). Product-level analysis shows that the impact would be entirely for small trucks due to Iran's elevated tariff for this product (40\%). Exports would also increase for chemicals and plastics, and-to some extent-for foodstuff (mostly chocolate products and biscuits). Armenia's imports would also increase by $\$ 43$ million for mineral products and base metals, including $\$ 19$ million for petroleum bitumen (asphalt). Imports would also increase by $\$ 36$ million for chemicals and plastics, including polyethylene ( $\$ 16$ million), a plastic used in food containers. 


\section{Figure 18: Trade Impact of Eurasian Economic Union-Iran Free Trade Agreement, by Sector}
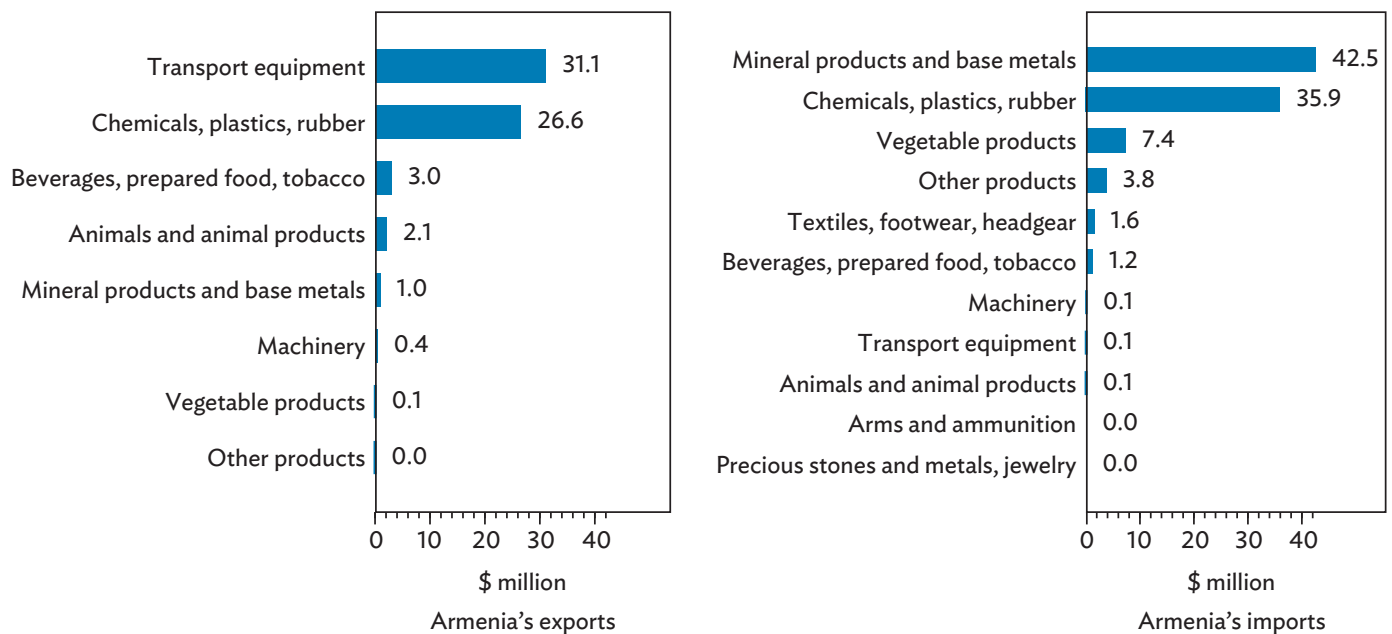

Note: Results from the partial equilibrium tool. Sectors correspond to an ad hoc aggregation of sections in the Harmonized System. Source: Authors' calculations.

\section{Free Trade Agreement between the Eurasian Economic Union and the People's Republic of China}

Armenia runs a trade deficit with the PRC. Machinery accounts for $45 \%$ of imports from the PRC, followed by textiles and footwear (16\%) (Figure 19). Copper accounts for most of Armenia's exports to the PRC (\$95 million in 2018), with the share of textiles and footwear increasing since 2016.

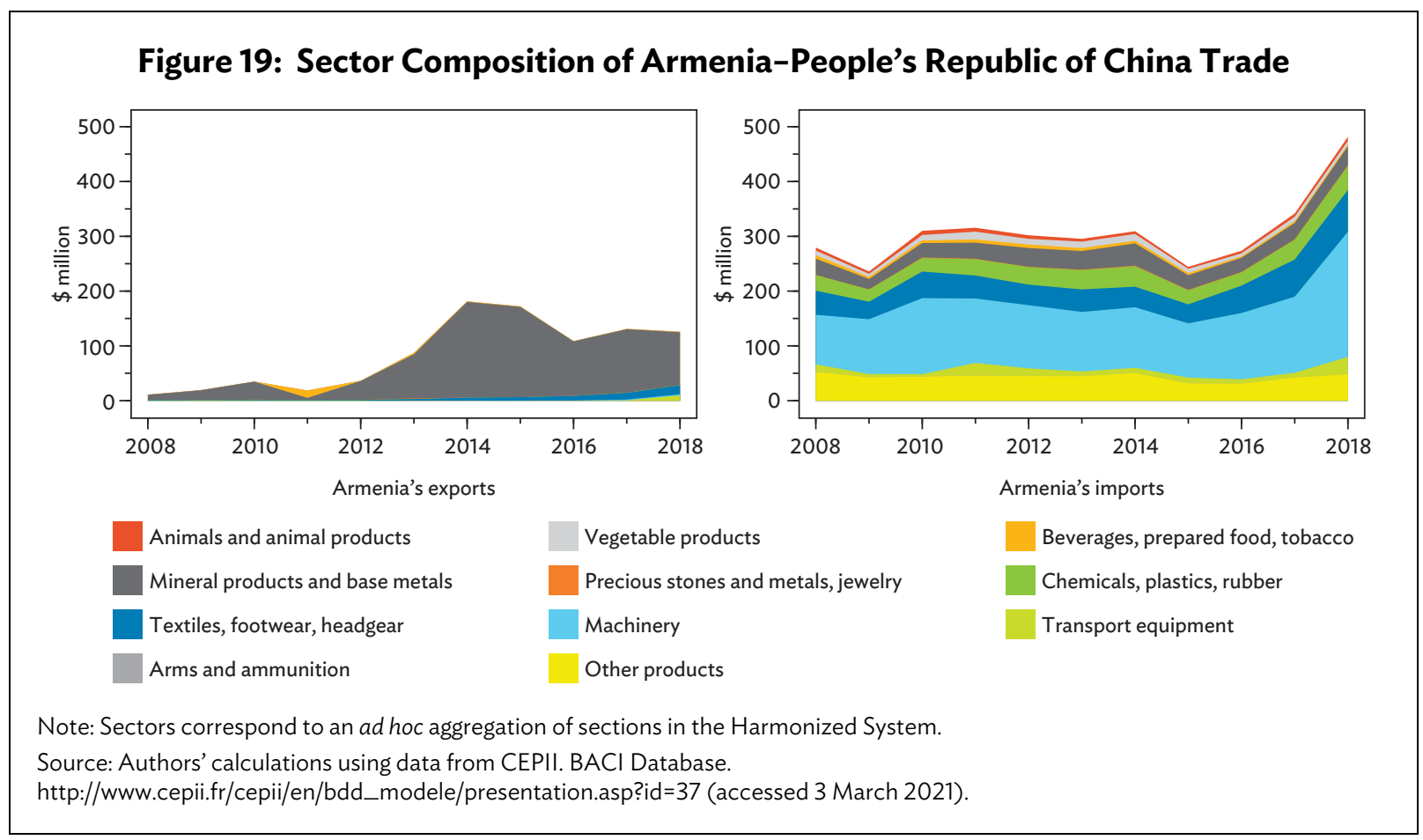




\section{General Equilibrium Welfare and Trade Impacts}

The general equilibrium analysis indicates that an FTA with the PRC would increase Armenia's welfare by $0.7 \%$-more than twice the impact of an FTA with Iran (Figure 20). Among EEU members, the Kyrgyz Republic would reap the largest welfare gains (2.9\%), followed by Kazakhstan (1.1\%). ${ }^{24}$ Armenia's manufacturing exports to the PRC would increase by $9 \%$ ( $\$ 12$ million), largely at the expense of exports to the Russian Federation ( $\$ 8$ million). Manufacturing imports from the PRC would increase by $20 \%$ ( $\$ 98$ million), largely at the expense of imports from the world ( $\$ 64$ million).

Figure 20: Welfare and Trade Impact of Eurasian Economic Union-People's Republic of China Free Trade Agreement, by Partner

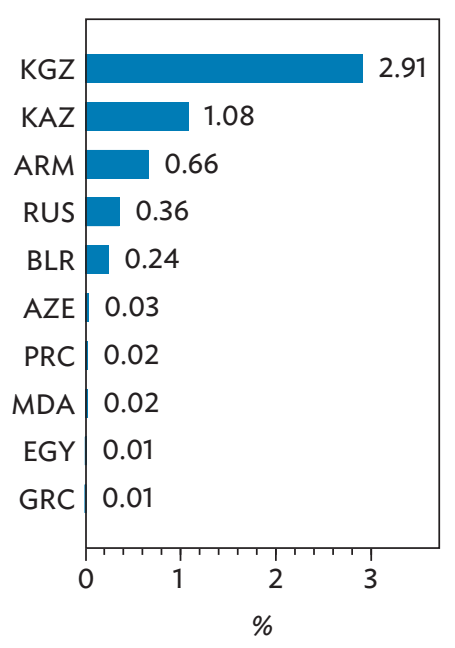

Top 10 welfare impacts

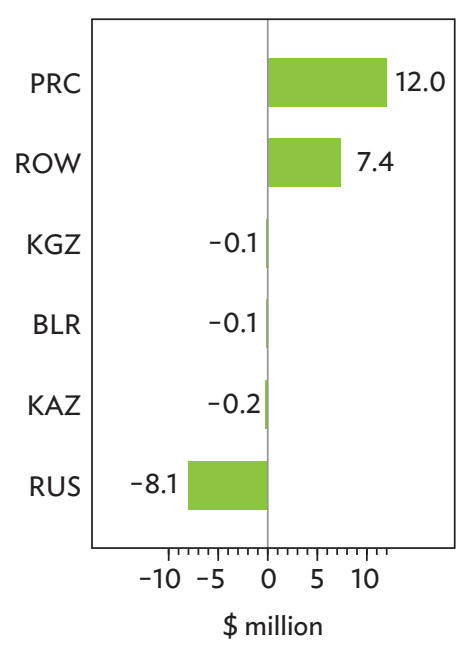

Impact on Armenia's exports

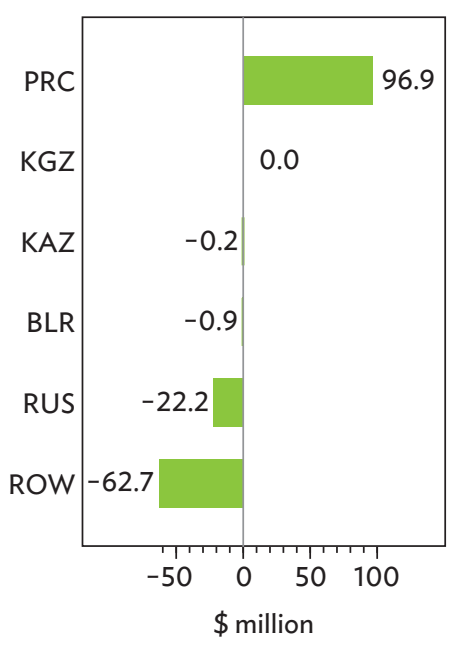

Impact on Armenia's imports

$\mathrm{ARM}=$ Armenia, $\mathrm{AZE}=$ Azerbaijan, $\mathrm{BLR}=$ Belarus, $\mathrm{EGY}=$ Egypt, $\mathrm{GRC}=$ Greece, $\mathrm{KAZ}=$ Kazakhstan, $\mathrm{KGZ}=$ Kyrgyz Republic, MDA = Moldova, $\mathrm{PRC}=$ People's Republic of China, ROW = Rest of the World, RUS = Russian Federation.

Note: Results from the general equilibrium tool.

Source: Authors' calculations.

\section{Partial Equilibrium Impact}

As in previous cases, the partial equilibrium trade impact exceeds the general equilibrium impact. Armenia's exports to the PRC would increase by 38\% ( $\$ 48$ million), against $10 \%$ in the general equilibrium. At the same time, imports from the PRC would increase by $32 \%$ ( $\$ 155$ million), against $20 \%$ in the general equilibrium.

Armenia's exports would mostly increase for transport equipment (Figure 21), entirely accounted for by medium-sized cars ( $\$ 46$ million). This might however be an artifact as the counterfactual exercise relies on 2018 as the baseline when Armenia's re-exports of used cars were abnormally large. The increase in imports would be more diversified, starting with machinery ( $\$ 53$ million), including television sets ( $\$ 24$ million), refrigerators ( $\$ 4$ million), and bicycles and washing machines ( $\$ 3$ million each). Imports would also increase for chemicals, plastics, and rubber ( $\$ 25$ million) and transport equipment ( $\$ 19$ million), including mid-sized cars ( $\$ 6$ million) and tires ( $\$ 5$ million).

24 The PRC accounts for $23 \%$ of Kazakhstan's imports and $53 \%$ of the Kyrgyz Republic's imports. 
Figure 21: Trade Impact of Eurasian Economic Union-People's Republic of China Free Trade Agreement, by Sector
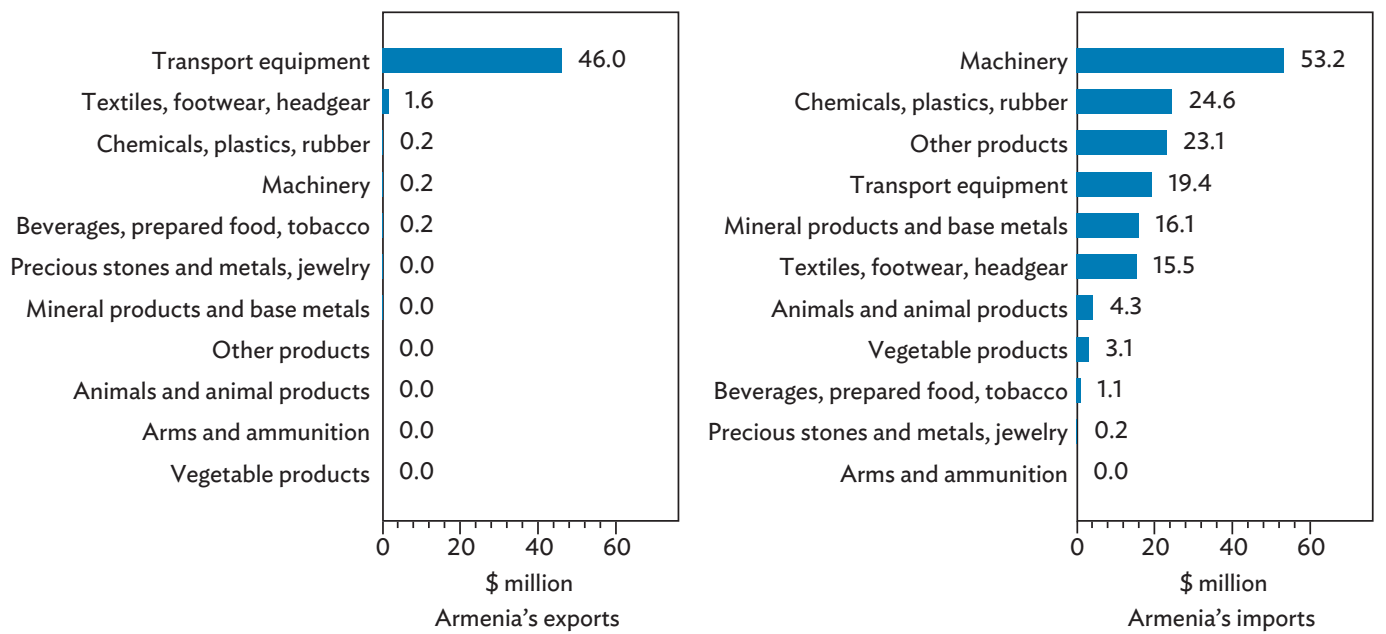

Note: Results from the partial equilibrium tool. Sectors correspond to an ad hoc aggregation of sections in the Harmonized System. Source: Authors' calculations.

\section{Loss of European Union Generalised Scheme of Preference Eligibility}

Armenia imports a wide range of products from the EU, but it mostly exports copper; either non-manufactured ores (under "minerals") or manufactured metal (under "base metals") (Figure 22). The bilateral trade balance with the EU remains in deficit despite increased copper exports since 2015. Imports from the EU fell in 2015-2016 as GDP growth slowed in Armenia, but they quickly recovered. This recovery of imports was particularly strong for industrial machinery, notably to support the development of the domestic agribusiness sector.

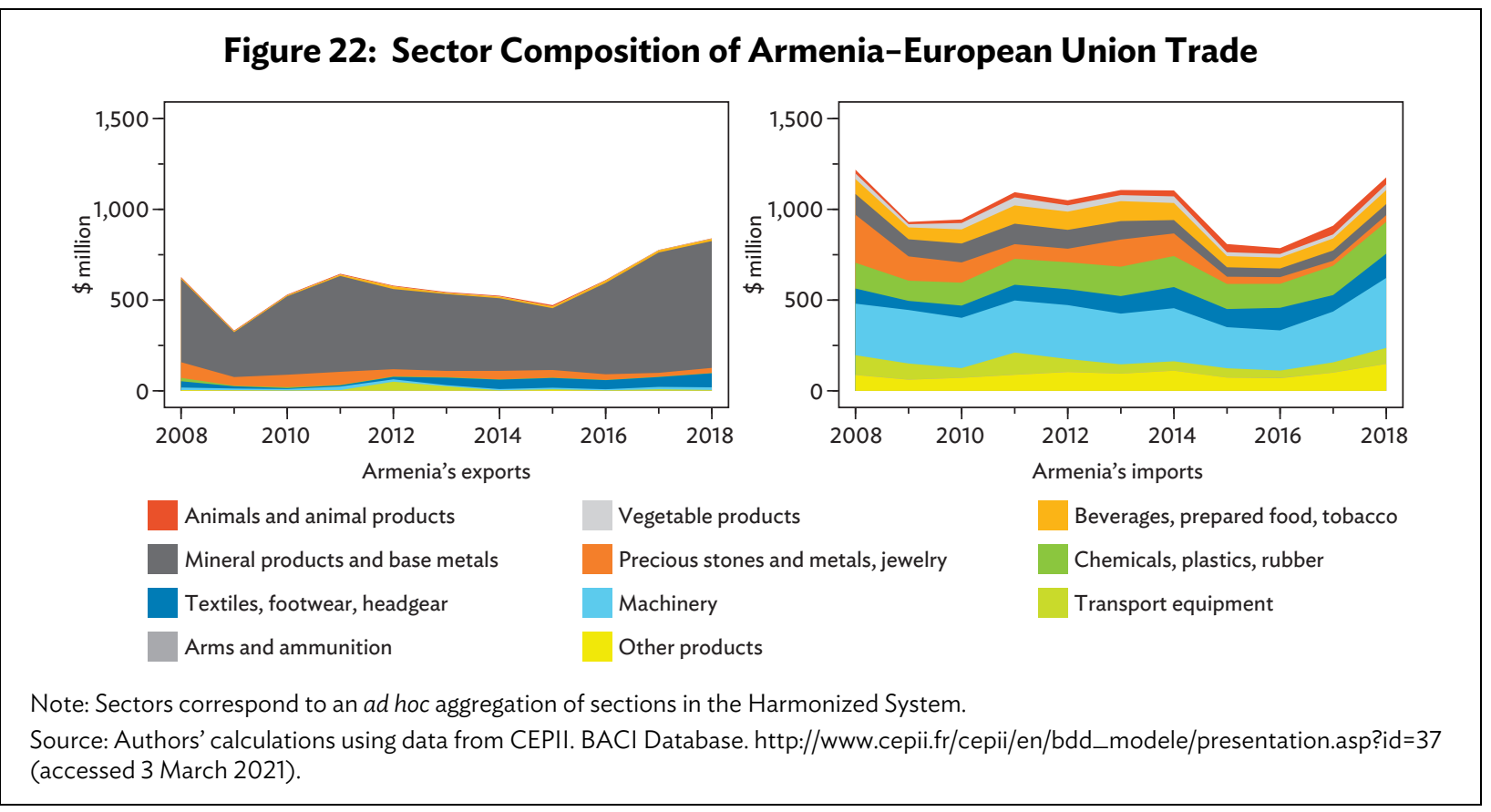




\section{General Equilibrium Welfare and Trade Impacts}

The general equilibrium tool indicates that the loss of eligibility to the EU's GSP and GSP+ should decrease Armenia's welfare by $0.1 \%$ and manufacturing exports to the EU by $12 \%$ ( $\$ 35$ million) (Figure 23). Exports to Germany should be the most affected ( $\$ 23$ million), followed by Italy ( $\$ 6$ million). Part of the foregone exports to the EU should be reallocated to other markets, notably the Russian Federation. In terms of net impact, Armenia's manufacturing exports should decline by $0.9 \%$ (-\$17 million).

\section{Figure 23: Welfare and Trade Impact of the Loss of European Union Generalised Scheme of Preferences Eligibility, by Partner}

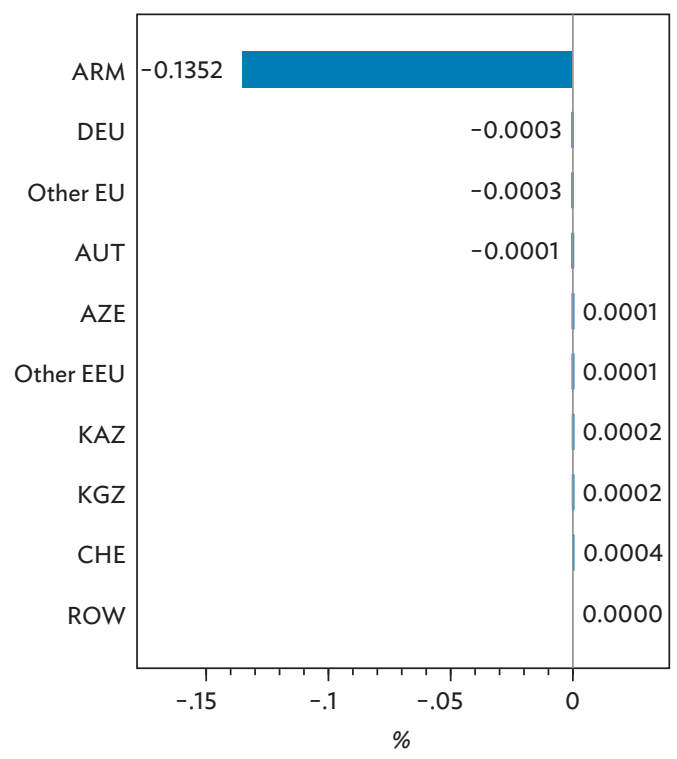

Welfare impact

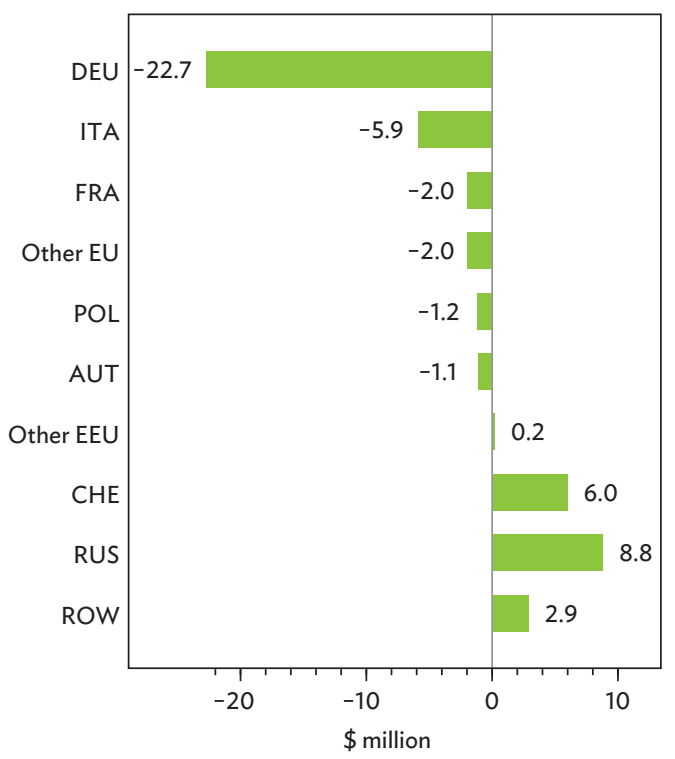

Impact on Armenia's exports

$\mathrm{ARM}=$ Armenia, $\mathrm{AUT}=$ Austria, $\mathrm{AZE}=$ Azerbaijan, $\mathrm{CHE}=$ Switzerland, $\mathrm{DEU}=$ Germany, $\mathrm{EEU}=$ Eurasian Economic Union,

$\mathrm{EU}=$ European Union, FRA = France, ITA = Italy, KAZ = Kazakhstan, $\mathrm{KGZ}=$ Kyrgyz Republic, $\mathrm{POL}=$ Poland, ROW = Rest of the World, RUS = Russian Federation.

Note: Results from the general equilibrium tool.

Source: Authors' calculations.

This minimal impact is mostly due to the limited tariff reductions provided by GSP+, given the product composition of Armenia's exports to the EU. Although it is not a manufactured good-and thus excluded from the general equilibrium analysis-copper accounted for $45 \%$ of Armenia's exports to the EU as of 2018, and the EU does not impose tariffs on copper (Table 5). The EU also does not impose tariffs on raw copper, which accounts for $7 \%$ of Armenia's bilateral exports. For ferromolybdenum alloys (23\% of Armenia's exports to the EU), GSP+ only provides a minimal advantage as the EU's MFN tariff is 2.7\%. The moderate effect of GSP+ on exports to the EU thus mostly arises from aluminum foil and apparel, which are also significant bilateral exports. 
Table 5: Armenia's Exports to the European Union: 2018

\begin{tabular}{lccc}
\hline & \$ million & \% of exports to the EU & EU's MFN tariff \\
\hline Total & 831 & $100 \%$ & - \\
Copper ores and raw copper & 372 & $45 \%$ & $0.0 \%$ \\
Ferromolybdenum & 193 & $23 \%$ & $2.7 \%$ \\
Aluminum foil & 97 & $12 \%$ & $7.5 \%$ \\
Non-knitted apparel & 76 & $9 \%$ & $12.0 \%$ \\
Total of top-5 products above & 738 & $89 \%$ & - \\
\hline
\end{tabular}

$\mathrm{EU}=$ European Union; MFN = most favored nation; $-=$ not applicable.

Sources: Authors' calculations using data from CEPII. BACI Database. http://www.cepii.fr/cepii/en/bdd_modele/presentation.asp?id=37 (accessed 3 March 2021); International Trade Center. Market Access Map. https://www.macmap.org/ (accessed 28 September 2021).

\section{Partial Equilibrium Impact}

The partial equilibrium tool suggests that the loss of GSP+ eligibility should reduce Armenia's exports to the EU by $19 \%$ ( $\$ 156$ million), an impact slightly larger than the reduction in manufacturing exports from the general equilibrium tool (-12\%).

Exports of metals-ferromolybdenum and aluminum foil-should decline the most ( $\$ 139$ million), followed by textiles (-\$16 million) (Figure 24). These products all make up a large share of Armenia's exports to the EU and exports are either very elastic to tariff increases (e.g., ferromolybdenum alloy has a tariff elasticity of -21) or will face high tariffs once Armenia's exports are subject to the EU's MFN (e.g., the EU's MFN tariff for non-knitted clothing is 12\%).

Figure 24: Impact of the Loss of European Union Generalised Scheme of Preferences Eligibility on Armenia's Exports, by Sector
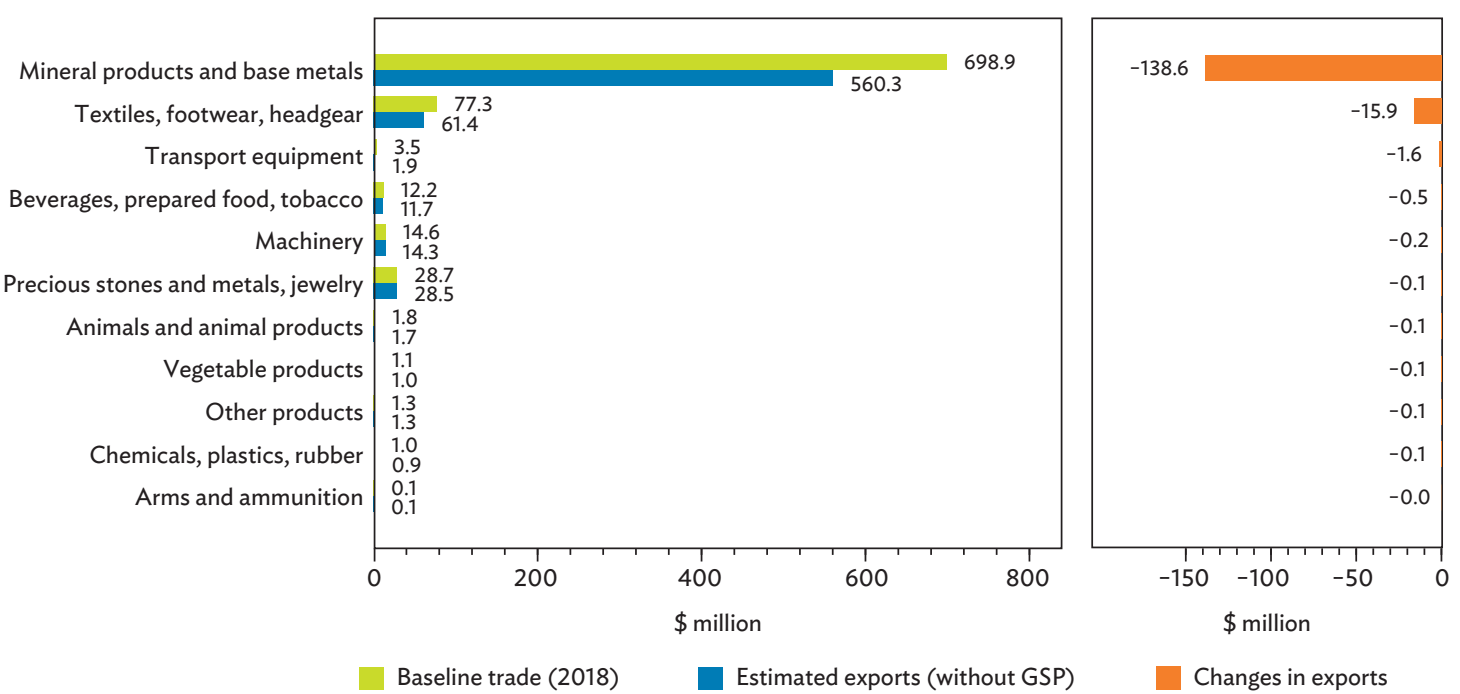

GSP $=$ Generalised Scheme of Preferences.

Note: Results from the partial equilibrium tool. Sectors correspond to an ad hoc aggregation of sections in the Harmonized System. Source: Authors' calculations. 


\section{CONCLUSION}

The general and partial equilibrium tools proposed in this paper are both derived from the structural gravity literature, and complement each other. The general equilibrium tool quantifies the impact of tariff changes on welfare and trade, including trade reallocation from or to partners with which tariffs have not been modified. Data limitations do not allow the assessment of impacts at the product level; and the resulting impacts only pertain to tariffs affecting trade in manufactured goods. The partial equilibrium tool also only allows quantifying the direct trade impact of tariff changes; but this impact can be broken down across 5,020 products.

As an intermediate input into the partial equilibrium tool, product-level trade elasticities are estimated using two specifications. The elasticities from the specification with country-pair fixed effects are novel, while the elasticities from the specification with explicit gravity controls align with other elasticities from the structural gravity literature. Given the better product coverage of the latter, the partial equilibrium tool relies on those.

When applied to four scenarios of tariff changes affecting Armenia, these tools allow the following conclusions. The convergence of Armenia's tariffs to the EEU CET by 1 January 2022 should reduce Armenia's welfare by $1.6 \%$. These effects arise from the fact that the EEU further constrains Armenia's access to foreign suppliers. Market access within the EEU does not improve, however, as Armenia already traded with all other members on a duty-free basis. This assessment only considers the impact of the EEU through tariff changes, excluding changes that may affect nontariff barriers and FTA opportunities within a larger trading block. In terms of trade impact, the CET is expected to reduce Armenia's imports by $1.5 \%$ (general equilibrium tool) to $12.3 \%$ (partial equilibrium tool). The impact is expected to concentrate on Armenia's imports from the EU, the PRC, and Turkey; and on chemicals and plastics, and transportation equipment.

An EEU-Iran FTA would increase Armenia's welfare by $0.3 \%$. General equilibrium results indicate that total exports would increase by $0.7 \%$, and exports to Iran would more than double. Total imports would increase by $0.4 \%$, with imports from Iran rising by $26 \%$. Partial equilibrium results suggest that exports would mostly increase for transportation equipment, and chemicals and plastics, and that imports would mostly increase for chemicals and plastics, and mineral products.

An EEU-PRC FTA would increase Armenia's welfare by $0.7 \%$. General equilibrium results indicate that total exports would increase by $0.6 \%$, and exports to the PRC would increase by $41 \%$. Total imports would increase by $0.3 \%$, with imports from the PRC rising by $20 \%$. Partial equilibrium results suggest that exports would mostly increase for transportation equipment and that imports would mostly increase for machinery.

These two potential FTAs alone would cancel out close to two-thirds of the negative welfare impact of the EEU. This suggests that the welfare impact of the EEU might be positive in the longer term, to the extent that it provides opportunities to improve Armenia's market access through FTAs negotiated by the EEU itself. Given the structure of Armenia's trade, liberalizing trade between the EEU and partners such as Iraq and Switzerland would also bring significant gains.

Finally, the loss of eligibility to the EU GSP scheme should reduce welfare in Armenia by at least $0.1 \%$, decreasing total exports by $0.9 \%$ (general equilibrium) to $3.3 \%$ (partial equilibrium) and exports to the EU by $12 \%$ (general equilibrium) to 19\% (partial equilibrium). 


\section{REFERENCES}

Anderson, James E., and Eric van Wincoop. 2003. "Gravity with Gravitas: A Solution to the Border Puzzle." American Economic Review 93 (1): 170-92.

Arkolakis, Costas, Arnaud Costinot, and Andrés Rodríguez-Clare. 2012. "New Trade Models, Same Old Gains?" American Economic Review 102 (1): 94-130.

ADB. 2021. "The Impact of Tariff Changes on Armenia's Foreign Trade." Technical Report. Asian Development Bank, Manila.

Baier, Scott L., Jeffrey H. Bergstrand, and Michael Feng. 2014. "Economic Integration Agreements and the Margins of International Trade." Journal of International Economics 93 (2): 339-50.

Baier, Scott L., Yoto V. Yotov, and Thomas Zylkin. 2019. “On the Widely Differing Effects of Free Trade Agreements: Lessons from Twenty Years of Trade Integration.” Journal of International Economics 116: 206-26.

Broda, Christian, and David E. Weinstein. 2006. "Globalization and the Gains from Variety." Quarterly Journal of Economics 121 (2): 541-85.

Caliendo, Lorenzo, and Fernando Parro. 2015. "Estimates of the Trade and Welfare Effects of NAFTA." Review of Economic Studies 82 (1): 1-44

CEPII. 2021. BACI Database. Centre d'Etudes Prospectives et d'Informations Internationales. http://www.cepii.fr/cepii/en/bdd_modele/presentation.asp?id=37 (accessed 3 March 2021).

Chaney, Thomas. 2008. "Distorted Gravity: The Intensive and Extensive Margins of International Trade." American Economic Review 98 (4): 1707-21.

Eaton, Jonathan, and Samuel Kortum. 2002. "Technology, Geography, and Trade.” Econometrica 70 (5): 1741-79.

EU. 2012. "Regulation (EU) No 978/2012 of the European Parliament and of the Council of 25 October 2012." Official Journal of the European Union 55: 1-82.

_. 2021. “Commissions Delegated Regulation (EU) 2021/114 of 25 September 2020.” Official Journal of the European Union 64: 5-6.

Feenstra. Robert C. 1994. "New Product Varieties and the Measurement of International Prices." American Economic Review 84 (1): 157-77.

Fontagné, Lionel, Houssein Guimbard, and Gianluca Orefice. 2019. "Product-level Trade Elasticities.” CEPII Working Paper No. 2019-17. Centre d'Etudes Prospectives et d'Informations Internationales, Paris. 
Gnutzmann, Hinnerk, and Arevik Gnutzmann-Mkrtchyan. 2020. "The Cost of Borders: Evidence from the Eurasian Customs Union." Hanover Economic Papers No. 664. Leibniz Universität, Hannover.

Head, Keith, Thierry Mayer, and John Ries. 2010. "The Erosion of Colonial Trade Linkages after Independence.” Journal of International Economics 81 (1): 1-14.

Head, Keith, and Thierry Mayer. 2014. "Gravity Equations: Workhorse, Toolkit, and Cookbook." In Handbook of International Economics 4, edited by Gita Gopinath, Elhanan Helpman, and Kenneth Rogoff, 131-195. Amsterdam: Elsevier B.V.

Isakova, Asel, Zsoka Koczan, and Alexander Plekhanov. 2016. "How Much do Tariffs Matter? Evidence from the Customs Union of Belarus, Kazakhstan and Russia." Journal of Economic Policy Reform 19 (2): 166-84.

International Trade Center. 2021. Market Access Map Database. https://www.macmap.org/ (accessed 28 September 2021).

Krugman, Paul R. 1979. “Increasing Returns, Monopolistic Competition, and International Trade." Journal of International Economics 9: 469-479.

Melitz, Marc J. 2003. "The Impact of Trade on Intra-Industry Reallocations and Aggregate Industry Productivity.” Econometrica 71 (6): 1695-1725.

Ossa, Ralph. 2015. “Why Trade Matters After All.” Journal of International Economics 97 (2): 266-77

Santos Silva, João, and Silvana Tenreyro. 2006. "The Log of Gravity." Review of Economics and Statistics 88 (4): 641-58.

Simonovska, Ina, and Michael E. Waugh. 2014. "The Trade Elasticity of Trade: Estimates and Evidence.” Journal of International Economics 92: 34-50.

Stawowy, Wojciech. 2021. "Calculation of Ad Valorem Equivalents of Non-ad valorem TariffsMethodology Notes.” Draft. United Nations Conference on Trade and Development, Geneva.

Tinbergen, Jan. 1962. Shaping the World Economy: Suggestions for an International Economic Policy. New York: Twentieth Century Fund.

UN. 2021. UN Comtrade Database. United Nations. https://comtrade.un.org/ (accessed 3 March 2021).

UNCTAD. 2021. Trade Analysis Information System. United Nations Conference on Trade and Development. https://wits.worldbank.org/tariff/trains/country-byhs6product.aspx?lang=en (accessed 12 March 2021).

UNIDO. 2021. Industrial Statistics database (INDSTAT2). United Nations Industrial Development Organization. https://www.unido.org/resources/statistics/statistical-databases/indstat2-2015edition (accessed 26 August 2021). 
Vinokurov, Evgeny. 2017. "Eurasian Economic Union: Current State and Preliminary Results." Russian Journal of Economics 3 (1): 54-70.

WTO. 2018. "Factual Presentation: Treaty on Accession of the Republic of Armenia to the Eurasian Economic Union (Goods and Services)." Report by the Secretariat. WT/REG363/1. World Trade Organization, Geneva.

Yotov, Yoto V., Roberta Piermartini, José-Antonio Monteiro, and Mario Larch. 2016. An Advanced Guide to Trade Policy Analysis: The Structural Gravity Model. Geneva: World Trade Organization. 


\section{Gravity-Based Tools for Assessing the Impact of Tariff Changes}

This paper presents empirical tools to quantify the impacts of tariff changes on trade and welfare. The first tool estimates the impact on bilateral trade for 5,020 products in a partial equilibrium framework. The second tool quantifies the general equilibrium impact on bilateral aggregate trade, allowing estimation of trade reallocation and welfare changes. These tools are used to estimate the impact of tariff changes affecting Armenia, including the alignment with the external tariff of the Eurasian Economic Union (EEU), free trade agreements between the EEU and other economies, and the loss of beneficiary status for the European Union's Generalised Scheme of Preferences.

\section{About the Asian Development Bank}

ADB is committed to achieving a prosperous, inclusive, resilient, and sustainable Asia and the Pacific, while sustaining its efforts to eradicate extreme poverty. Established in 1966, it is owned by 68 members -49 from the region. Its main instruments for helping its developing member countries are policy dialogue, loans, equity investments, guarantees, grants, and technical assistance. 